\title{
A Dual-Doppler Radar Study of Longitudinal-Mode Snowbands
}

\author{
Part II: Influence of the Kinematics of a Longitudinal-Mode Snowband on \\ the Development of an Adjacent Snowband
}

\author{
By Naohiro Yoshimoto \\ Division of Science Education, Osaka Kyoiku University, Osaka, Japan \\ Yasushi Fujiyoshi \\ Institute of Low Temperature Science, Hokkaido University, Sapporo, Japan \\ and
}

Takao Takeda

Institute for Hydrospheric-Atmospheric Sciences, Nagoya University, Nagoya, Japan

(Manuscript received 1 October 1999, in revised form 27 March 2000)

\begin{abstract}
Two longitudinal-mode snowbands (bands I and II) were observed over the Ishikari Bay, Hokkaido, Japan during a wintertime cold-air outbreak. The three-dimensional kinematic structure of a snowband (band II) was examined in detail using dual-Doppler radar data. Band II noticeably developed over the Ishikari Bay. A high-reflectivity (approximately $35 \mathrm{dBZ}$ at the maximum) zone was formed along the band axis and characterized the radar-echo structure of band II. The high-reflectivity zone of band II had the airflow structure dominated by circulations in vertical cross sections perpendicular to the band axis.

The interactions between the two snowbands were discussed. Interestingly, it was found that radarecho bridges existed at the low levels between the two snowbands. The radar-echo bridges were formed in association with low-level outflows from the meso- $\gamma$-scale convective cloud systems composing band I. The low-level outflows moved toward band II with time and penetrated into band II. This caused strong low-level convergence and the enhancement of updrafts in band II. Consequently, stronger radar-echoes were formed in band II and band II rapidly developed. Ice/snow particles were transported from band I into band II by the low-level outflows. It was considered that the rapid growth of these particles in the enhanced updrafts in band II would have contributed to the rapid development of band II.
\end{abstract}

\section{Introduction}

The observation of snowstorms was carried out around the Ishikari Bay, Hokkaido, Japan, from 25 December 1991 to 10 February 1992 (Fig. 1). Two different types of longitudinal-mode snowbands (designated as band I and band II in Fig. 2) were observed by the dual-Doppler radar system of the Institute for Hydrospheric-Atmospheric Sciences

Corresponding author: Naohiro Yoshimoto, Division of Science Education, Osaka Kyoiku University, 4698-1 Asahigaoka, Kashiwara, Osaka 582-8582, Japan. E-mail: yoshimo@cc.osaka-kyoiku.ac.jp (C) 2000 , Meteorological Society of Japan
(IHAS), Nagoya University on 15 January 1992. Part I of this study (Fujiyoshi et al. 1998) showed three-dimensional kinematic structures of band I. Band II noticeably developed over the Ishikari Bay. It was considered that the development of band II would have been related with the topography around the Ishikari Bay (as stated in Part I). It has been known that snowbands influenced by terrain frequently appear and develop over the Ishikari Bay. Asuma and Kikuchi (1987) investigated the occurrence frequency of radar echoes over the Ishikari Bay during winter. They reported that when radar echoes moved from west-northwest the occurrence 


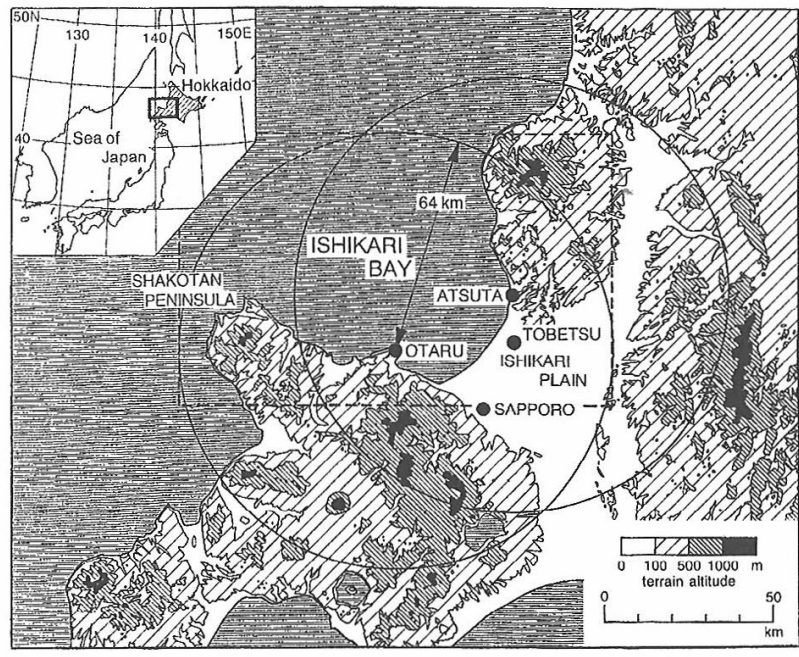

Fig. 1. Locations of the IHAS Doppler radars (Otaru and Atsuta), the area of quantitative radar observations (shown by two circles), and a topographic map of the observation area. The box outlined by the broken line corresponds with the radar display area shown in Figs. 2 and 4. The solid circles at Sapporo and Tobetsu indicate the sites of an upper-air sounding system and a radar of Sapporo City, respectively. The upper-left panel shows a large area map. The hatched area in this panel indicates Hokkaido. The box in this panel shows the enlarged segment.

frequency of radar echoes over the southern Ishikari Bay were higher than that over the other regions of the Ishikari Bay. Kikuchi et al. (1987) investigated the horizontal displacement of radar echoes over the Ishikari Bay during wintertime cold-air outbreaks. They reported that radar echoes near the Shakotan Peninsula and the Takashima Point (locating near Otaru) moved from more $10^{\circ}$ west than the other radar echoes over the Ishikari Bay. In these studies, however, the structures of snow clouds were not examined. Fujiyoshi et al. (1992) observed a snowband formed on the lee side of a mountain using a Doppler radar. They revealed that the snowband was composed of meso- $\gamma$-scale cloud systems. However, they were not able to observe the wind field within the snowband. Thus, one of the purposes of this paper is to describe the three-dimensional kinematic structure of a snowband influenced by terrain.

Part I revealed that the evolution of strong bandparallel winds played an important role in the organization and maintenance of the meso- $\gamma$-scale systems composing band I. In addition, it was revealed that the evaporation of ice/snow particles near the cloud top caused the formation of the strong bandparallel winds in the meso- $\gamma$-scale systems composing band I. This result suggests that the formation process of ice/snow particles plays an important role in the formation of the three-dimensional kinematic structures of longitudinal-mode snowbands. Although linear theories succeeded in cxplaining the formation of cloud streets by horizontal roll vortices (e.g., Asai 1970; Brown 1970; Kuettner 1971), they cannot explain the three-dimensional kinematic structures of longitudinal-mode snowbands.

Kobayashi et al. (1992) observed the merging phenomena of longitudinal-mode snowbands. They also observed that a new longitudinal-mode snowband appeared between two existing longitudinalmode snowbands. The radar-echo structures of longitudinal-mode snowbands changed largely through the merging of snowbands and the formation of new snowbands. Their results suggest that the interactions between longitudinal-mode snowbands may cause the changes of the kinematic structures of longitudinal-mode snowbands. Sakakibara et al. (1988) observed squall-line like snowbands using a Doppler radar. They discussed the spacing between snowbands. They suggested that the cold downdraft air would have inhibited the occurrence of new convective clouds, since it can be colder than the environmental air and change the static condition near the sea surface. This indicates that the kincmatics of a snowband may affect on the formation and evolution of an adjacent snowband. To clarify the maintenance mechanisms of longitudinalmode snowbands, it is necessary to investigate not only the internal structure of a snowband, but also the wind fields in the regions between snowbands. However, there have been no observations of the wind fields in the regions between snowbands. The second purpose of this paper is to discuss the interaction between the two snowbands. The data observed on 15 January 1992 also makes it possible to analyze the wind fields in the region between bands I and II.

In this paper, data obtained by the X-band dualDoppler radar system and the X-band radar of Sapporo City, which is installed at Tobetsu (see Fig. 1), were mainly used. The methods of analysis and the atmospheric conditions in this case were presented in Part I.

\section{Radar-echo structures of the two snow- bands}

Figure 3 illustrates the time series of the horizontal radar-echo patterns at an altitude of about $1.0 \mathrm{~km}$ observed by the radar at Tobetsu. Longitudinal-mode snowbands began to appear off the west of the Ishikari Bay at approximately 1100 LST (LST $=\mathrm{UTC}+9 \mathrm{~h})$. Two longitudinalmode snowbands (bands I and II) were recognized at 1130 LST. Other longitudinal-mode snowbands also existed off the west coast of Hokkaido. At 1300 LST, the western part of band II began to disappear off the west of the Shakotan Peninsula, although its 


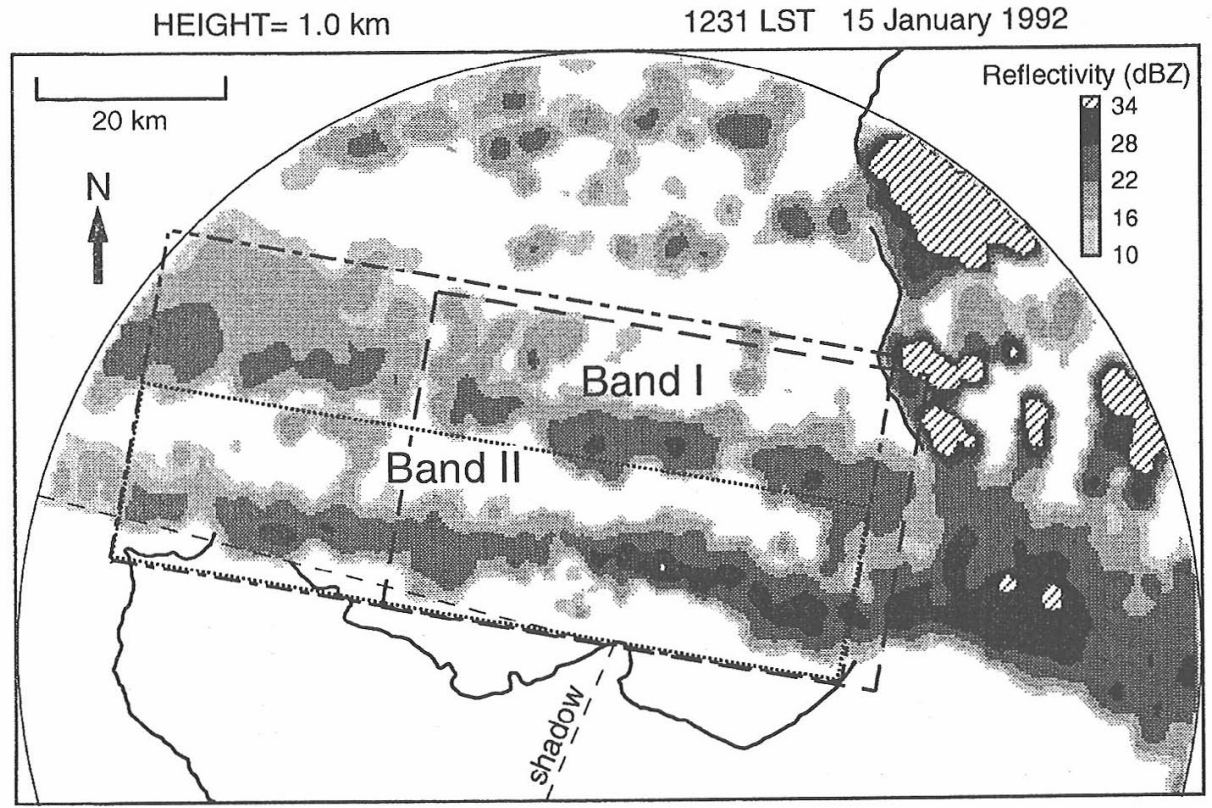

Fig. 2. Radar reflectivity pattern at an altitude of $1.0 \mathrm{~km}$ at 1231 LST 15 January 1992 . The hatched regions indicate ground echoes. The thick solid lines show the seashore. The region (labeled shadow) between the two broken lines indicates the region in which the collection of radar data was prevented by the terrain. The boxes outlined by the dotted line and the dot-dashed line correspond with the radar display areas in Figs. 9 and 13, respectively. The box outlined by the broken line corresponds with the radar display area in Figs. 14 and 15.

main part still existed over the Ishikari Bay. In this paper, the period between 1201 and 1337 LST will be analyzed, because bands I and II were simultaneously observed over the Ishikari Bay by the dualDoppler radars.

Figure 4 illustrates the horizontal distribution of the time-averaged (between 1201 and 1337 LST) radar echo at an altitude of $1.0 \mathrm{~km}$. During the period of observation, band II brought heavy snowfall on the Ishikari Plain. Same as Part I, the axes parallel and pcrpendicular to the alignment of the snowbands $\left(280^{\circ}\right)$ are referred as the $x$ axis and the $y$ axis, respectively. Velocity components along the $x$ and $y$ axes are denoted as $u$ and $v$, respectively. Figure 4 shows that the reflectivities of band II were a little high (exceeding $22 \mathrm{dBZ}$ ) near the northern edge of the Shakotan Peninsula, and were noticeably high (exceeding $28 \mathrm{dBZ}$ ) in the downstream side of Otaru.

Figure 5 shows the vertical cross section of band II along the white line $A B$ in Fig. 4. In the upstream part of band II $(x<-20 \mathrm{~km})$ the echo-top levels defined by the reflectivity of $10 \mathrm{dBZ}$ were nearly equal to, or lower than, the inversion level $(2.0 \mathrm{~km}$, see Fig. 3 in Part I). As shown in Fig. 5, the reflectivities were high (exceeding $22 \mathrm{dBZ}$ ) and the echotop level was a little bit high (exceeding $2.0 \mathrm{~km}$ ) near the northern edge of the Shakotan Peninsula $(-45 \mathrm{~km} \leq x<-25 \mathrm{~km})$. In the region between $x=-20 \mathrm{~km}$ and $x=2 \mathrm{~km}$, the reflectivities and the echo-top level noticeably increased with $x$, indicating the rapid development of clouds in this region. High reflectivities exceeding $28 \mathrm{dBZ}$ were found at $x \geq-7 \mathrm{~km}$. The highest echo-top level $(2.7 \mathrm{~km})$ was apparently higher than the inversion level. In the region between $x=-15 \mathrm{~km}$ and $x=2 \mathrm{~km}$, the radar echoes at the middle levels were stronger than those at the low levels, which suggests that strong updrafts sustained large ice/snow particles in the air. Based on these features, this paper will refer to the upstream part of band II $(x<-20 \mathrm{~km})$ as "the upstream region," the middle part of band II $(-20 \mathrm{~km} \leq x<2 \mathrm{~km})$ as "the intensifying region," and the downstream part $(x \geq 2 \mathrm{~km})$ as "the developed region."

Since wind fields could be derived in the intensifying region and the part of the developed region, this paper will examine the kinematic structures of band II in these regions (between $x=-20 \mathrm{~km}$ and $x=7 \mathrm{~km})$.

\section{Three-dimensional kinematic structure of band II}

\subsection{Mean structure}

In this subsection the mean structure of band II will be examined in the same way as that of band I (reported in Part I). Figure 6 shows vertical profiles of mean horizontal divergence, $\partial u / \partial x$, and $\partial v / \partial y$ 

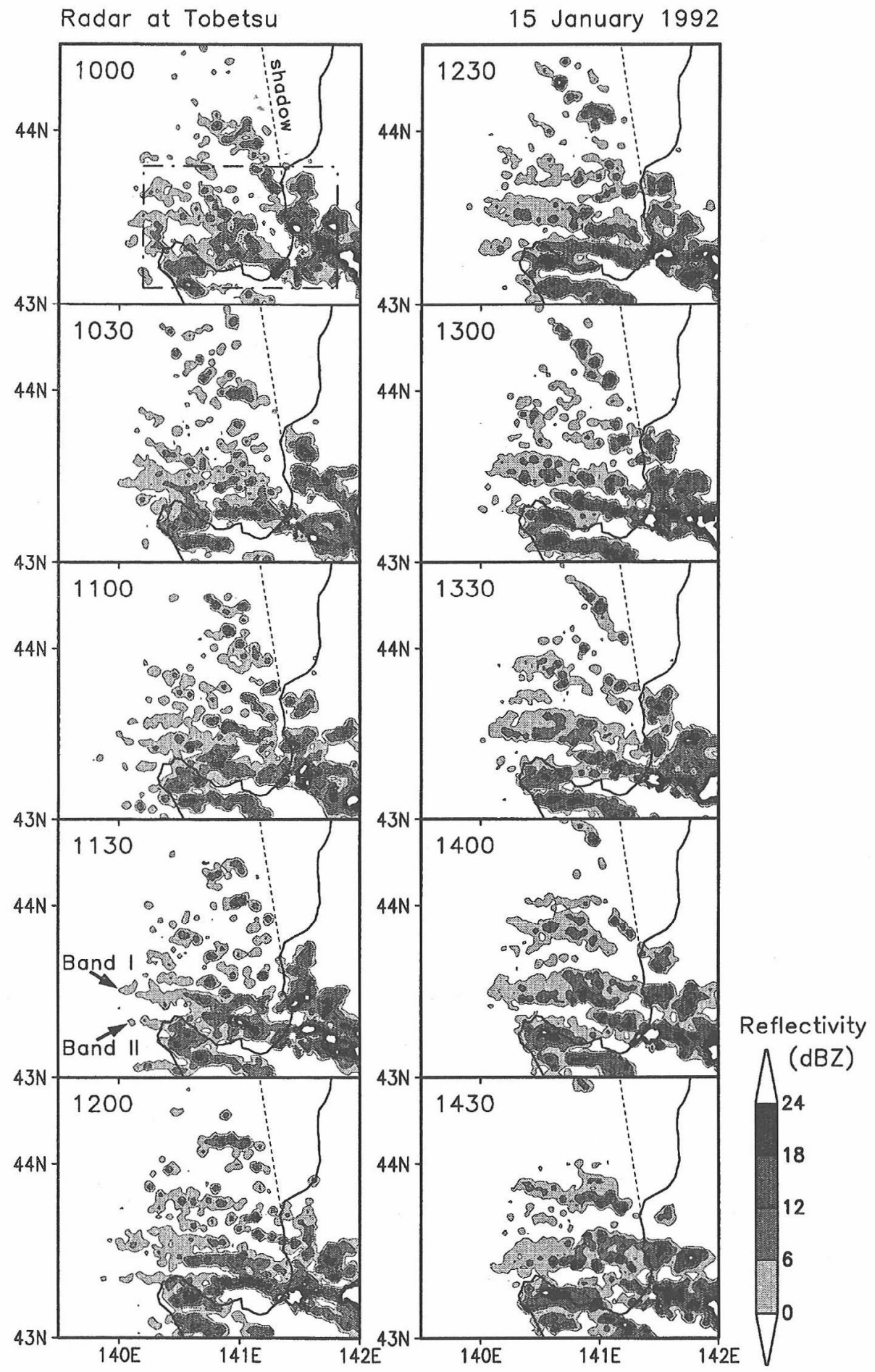

Fig. 3. Time series of radar reflectivity pattern observed by the radar at Tobetsu at an altitude of about $1.0 \mathrm{~km}$. The solid line in each panel indicates the seashore. In the first panel, the box outlined by the dot-dashed line corresponds with the radar display area shown in Figs. 2 and 4. The region to the right of the broken line (labeled shadow) indicates the region in which the collection of radar data was prevented by the terrain.

in the high-reflectivity (exceeding $25 \mathrm{dBZ}$ ) regions in the intensifying and developed regions of band II (thick lines). Averaging the data of band II between 1201 and 1325 LST derived them. The data of band
I (thin lines) are also shown for comparison. The profiles for band I are the same as those presented in Fig. 9 in Part I. Both the regions of band II show similar profiles: it is clear that convergence existed 


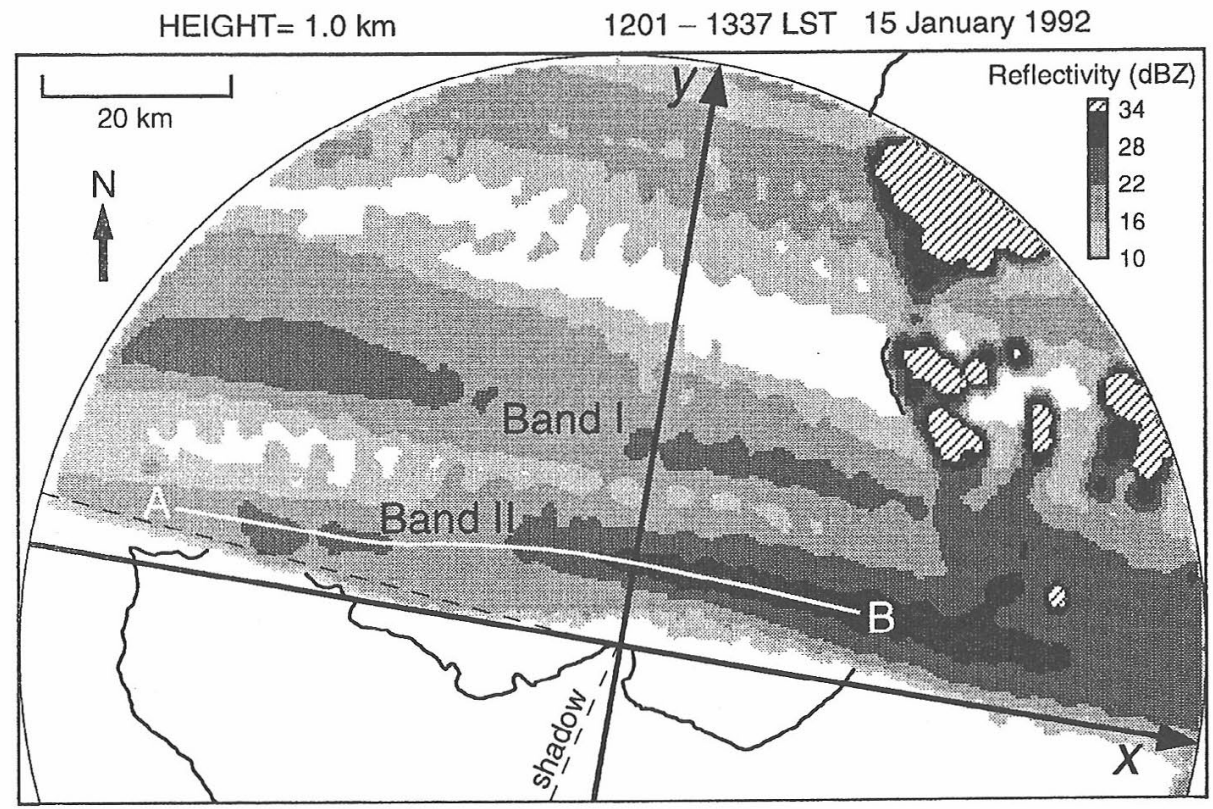

Fig. 4. Radar reflectivity pattern averaged from 1201 to 1337 LST at an altitude of $1.0 \mathrm{~km}$. The thick solid lines show the seashore. The region (labeled shadow) between the two broken lines indicates the region in which the collection of radar data was prevented by the terrain. The $x-y$ coordinate system used in this paper is denoted by arrows. The white line $A B$ shows the line along which the vertical cross section is displayed in Fig. 5.

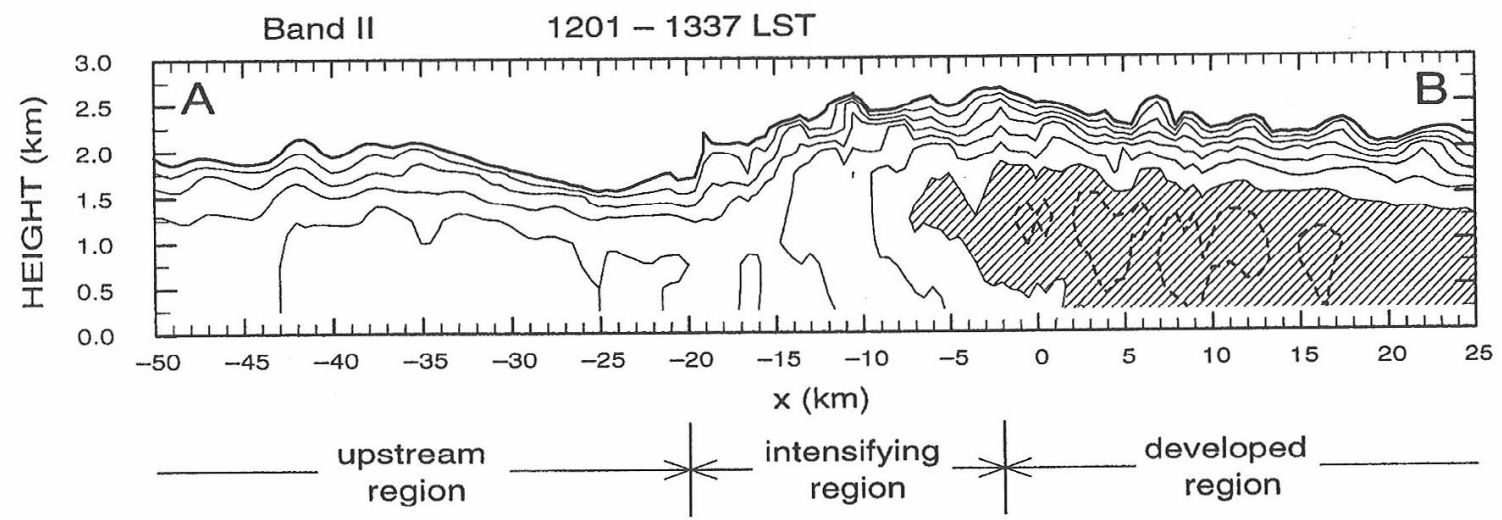

Fig. 5. Radar reflectivity pattern averaged from 1201 to 1337 LST in the vertical cross section along the white line $A B$ in Fig. 4 . The solid contours are drawn every $3 \mathrm{dBZ}$ above $10 \mathrm{dBZ}$. The broken contours indicate a reflectivity of $30 \mathrm{dBZ}$. The hatched regions show reflectivities of at least $28 \mathrm{dBZ}$.

below $1.0 \mathrm{~km}$, and divergence existed above $1.25 \mathrm{~km}$. The maximum convergence was situated at the lowest level. It should be noted that in the convergence layer the magnitude of $\partial v / \partial y$ was much larger than that of $\partial u / \partial x$. This was quite different from that in band I, where the magnitude of $\partial v / \partial y$ was comparable with that of $\partial u / \partial x$. In addition, the magnitude of the maximum convergence in band II was about five times larger than that in band I.

Figures 7 and 8 show the mean structures of the intensifying and developed regions of band II, respectively, in vertical cross sections perpendicular to the band axis. In Fig. 8, the term "no wind data" means the lack of wind data due to no scans in high elevation angles operated by the Doppler radar at Otaru. In the regions not observed by the Doppler radar at Otaru, an extension of reflectivity data was put using the data obtained by the Doppler radar at Atsuta. Reflectivity and airflow data in Figs. 7 and 8 were averaged between 1201 and 1313 LST, and between 1201 and $1325 \mathrm{LST}$, respectively, since another radar echo appeared in the southern outside of band II.

Figure 7 a shows the vertical cross section of mean 
(a) the intensifying region of band II

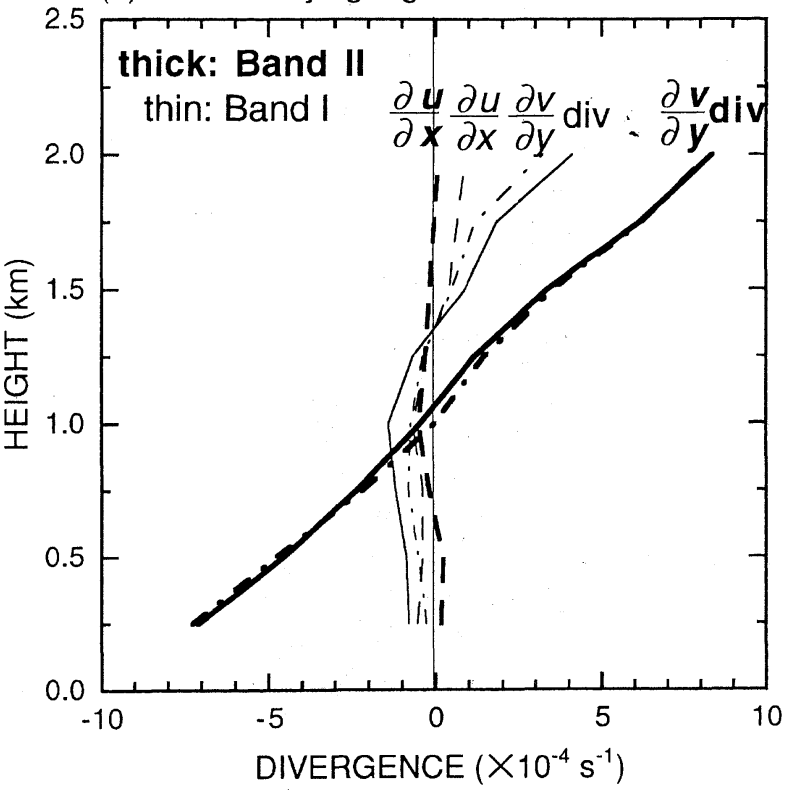

(b) the developed region of band II

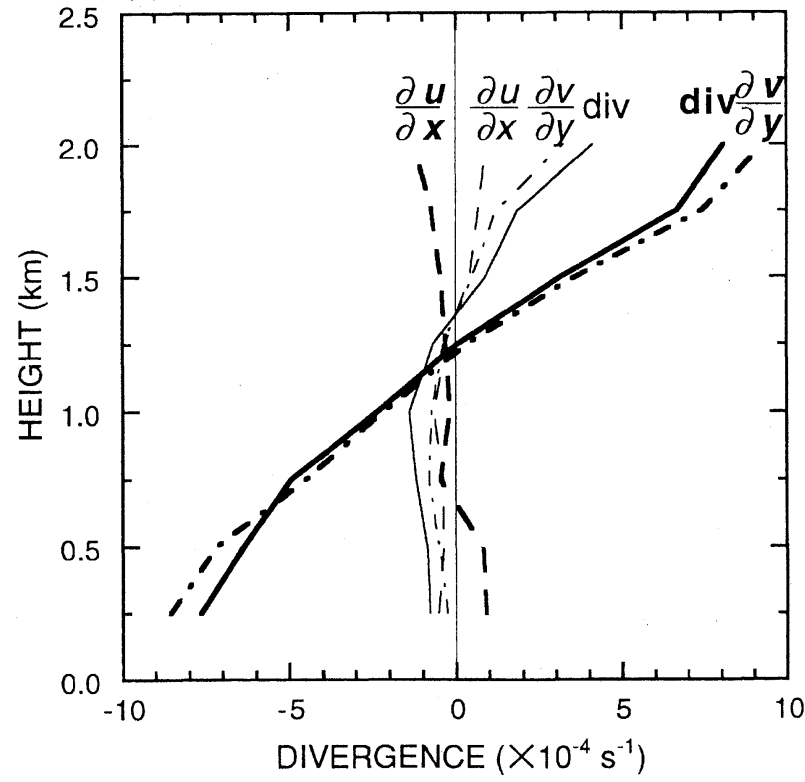

Fig. 6. Vertical profiles of horizontal divergence (solid lines), $\partial u / \partial x$ (broken lines), and $\partial v / \partial y$ (dot-dashed lines) averaged horizontally and temporally in the regions of high reflectivity of at least $25 \mathrm{dBZ}$ in the intensifying and developed regions of band II (thick lines). The averaged period for band II is between 1201 and 1325 LST. (a) The intensifying region of band II. The averaged region is $-12 \mathrm{~km} \leq x<-2 \mathrm{~km}$. (b) The developed region of band II. The averaged region is $-2 \mathrm{~km} \leq x<8 \mathrm{~km}$. In the both panels, the profiles for band I (thin lines) are also shown for comparison. The averaged period of band I is between 1201 and 1255 LST. The averaged region in band I is $-10 \mathrm{~km} \leq x<10 \mathrm{~km}$. reflectivity and airflow patterns in the intensifying region of band II. The echo-top level was higher than the inversion level $(2.0 \mathrm{~km})$. Figure $7 \mathrm{~b}$ shows the distribution of vertical velocities. Updrafts existed in the high-reflectivity region of the snowband $(y=8-$ $13 \mathrm{~km})$. The maximum updraft $\left(0.7 \mathrm{~m} \mathrm{~s}^{-1}\right)$ existed in the highest-reflectivity region at the middle levels $(y=11 \mathrm{~km})$. Downdrafts existed in the northern outside and the southern outside of the updrafts. The maximum downdraft had a speed of $0.5 \mathrm{~m} \mathrm{~s}^{-1}$. The distribution of the band-normal wind component $(v)$ in Fig. 7c shows that at the low levels strong convergence occurred in the highest-reflectivity region. Figure $7 \mathrm{~d}$ shows the vertical distribution of the band-parallel wind component $(u)$. Strong $u$ winds existed in the southern side of the snowband $(y=6-9 \mathrm{~km})$.

Figure $8 \mathrm{a}$ shows the vertical cross section of mean reflectivity and airflow patterns in the developed region of band II. The highest-reflectivity region existed in the central part of the snowband at the middle levels (as seen in Fig. 5). Updrafts occupied the snowband (Fig. 8b). The maximum updraft reached a speed of $0.6 \mathrm{~m} \mathrm{~s}^{-1}$. At the low levels, winds coming from the northern outside of band II and winds coming from the southern outside of band II encountered in the highest-reflectivity region.

\subsection{Time change of the airflow structure}

Figure 9 shows the time series of horizontal reflectivity patterns of band II at an altitude of $1.25 \mathrm{~km}$. The area shown in Fig. 9 corresponds with that outlined by the dotted line in Fig. 2. The upstream (left) part of band II was composed of cellular radar echoes with $5-10 \mathrm{~km}$ in size. The cellular radar echoes were aligned with the band axis at a nearly regular interval (approximately $8 \mathrm{~km}$ ) and moved in an average speed of $12.5 \mathrm{~m} \mathrm{~s}^{-1}$ along the band axis. The radar-echo structure in the upstream region of band II was similar to that of band I (reported in Part I). However, the radar-echo structure of band II noticeably changed over the Ishikari Bay. It is clear that downstream (right) part of band II had a quasi-steady high-reflectivity (exceeding $28 \mathrm{dBZ}$ ) zone along the band axis. The maximum reflectivity reached approximately $35 \mathrm{dBZ}$. Such a highreflectivity zone has not been found in band I. The high-reflectivity zone characterized the radar-echo structure of band II.

Figure 10 shows the time series of band-normal vertical structures of band II along the vertical broken lines in Fig. 9. The place of the vertical cross section was moved in phase with the cellular radar echo. The airflow data were also shown in the panels between 1231 LST and 1255 LST. The modification of the cellular radar echoes composing band II showed common features. In Fig. 10, the increase of the echo-top level occurred at $1219 \operatorname{LST}(y=9 \mathrm{~km})$. 


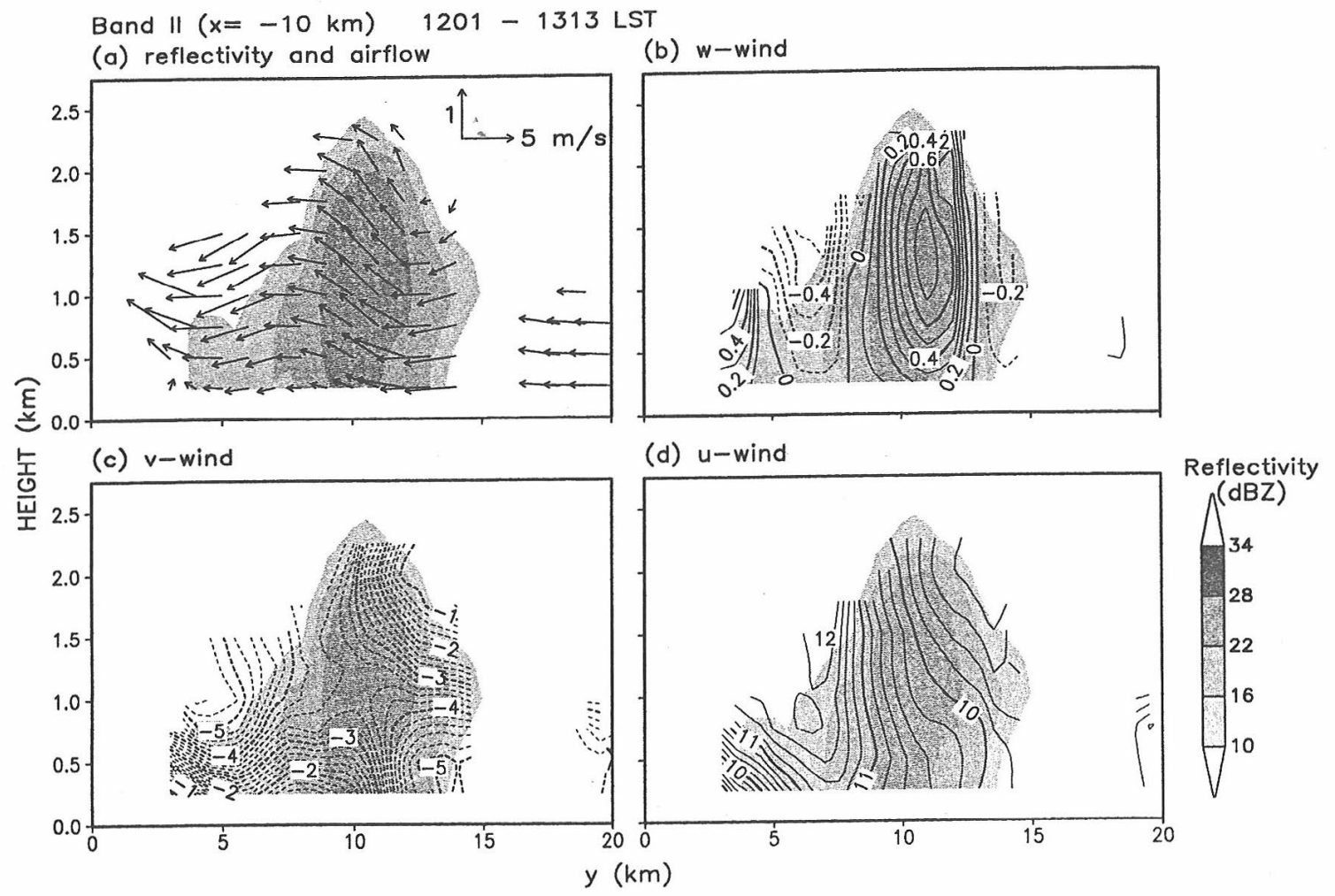

Fig. 7. Mean structure of the intensifying region of band II in a vertical cross section $(x=-10 \mathrm{~km})$ perpendicular to the band axis. The averaged period is between 1201 and 1313 LST. (a) Radar reflectivity and airflow. (b) Vertical wind velocity $w$. The contours are drawn every $0.1 \mathrm{~m} \mathrm{~s}^{-1}$. The broken lines indicate negative values. (c) Band-normal component $(v)$ of the horizontal winds $\left(\mathrm{m} \mathrm{s}^{-1}\right)$. The broken lines indicate negative values. (d) Band-parallel component $(u)$ of the horizontal winds $\left(\mathrm{m} \mathrm{s}^{-1}\right)$.

The radar-echo top rapidly increased in height with time and reached $2.75 \mathrm{~km}$ at $1243 \mathrm{LST}$. At this time, the maximum updraft (exceeding $1 \mathrm{~m} \mathrm{~s}^{-1}$ ) was observed. Although the radar-echo top gradually decreased in height with time after 1243 LST, the reflectivities increased with time and reached $35 \mathrm{dBZ}$ at 1301 LST. The panels at 1231 LST and 1237 LST show that the general structures were the same as the mean structure of the intensifying region of band II shown in Fig. 7. Also, the radar-echo and airflow structures at 1243 LST and 1249 LST were similar to the mean structure of the developed region of band II shown in Fig. 8.

Figure 11 shows horizontal cross sections of radar reflectivities and storm relative airflow in the intensifying and developed regions of band II at altitudes of $0.25,1.25$, and $2.0 \mathrm{~km}$. The area shown in Fig. 11 corresponds with the area outlined by the dot-dashed line in Fig. 9. The term "storm-relative airflow" means airflow relative to the mean motion of cellular radar echoes. At $0.25 \mathrm{~km}$ (Fig. 11a), it is clear that the encounters between the winds coming from the northern outside and the winds coming from the southern outside occurred in the central part of the snowband. The winds in the northern side of band II were in good agreement with the upper-sounding data observed at Sapporo (shown in the upper left of the first panel). The encounters between the two airflows formed strong convergence along the band axis. The maximum of convergence reached approximately $3 \times 10^{-3} \mathrm{~s}^{-1}$. Since at an altitude of $1.25 \mathrm{~km}$ (Fig. 11b) no strong convergence was found in the snowband, the strong convergence was restricted at the low levels (see also Figs. 6, 7, and 8). The figure at $2.0 \mathrm{~km}$ (Fig. 11c) clearly shows that radar echoes had a shape like a line. Strong divergence existed along the central part of the snowband. The winds in the southern side of band II at the lowest level will be discussed in Section 5 .

Figure 12 shows the time series of radar reflectivities and storm-relative airflows in a vertical cross section along the broken line $E F$ in Fig. 11. This cross section was chosen to cut the line of maximum convergence in band II at the lowest level. These figures clearly show that updrafts dominated in the vertical cross sections for the every time shown in Fig. 12. The maximum of the updrafts reached approximately $2 \mathrm{~m} \mathrm{~s}^{-1}$. In the intensifying region (between $x=-20 \mathrm{~km}$ and $x=-2 \mathrm{~km}$ ), the echo-top levels and the reflectivities rapidly increased with 
Band II $(x=0 \mathrm{~km}) \quad 1201$ - 1325 LST

(a) reflectivity and airflow

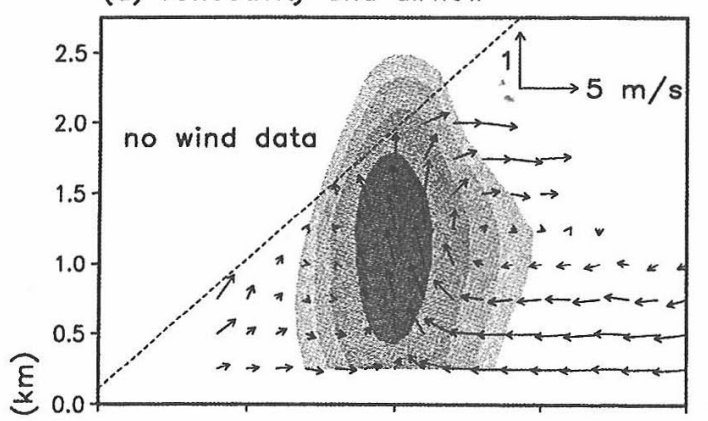

(b) w-wind
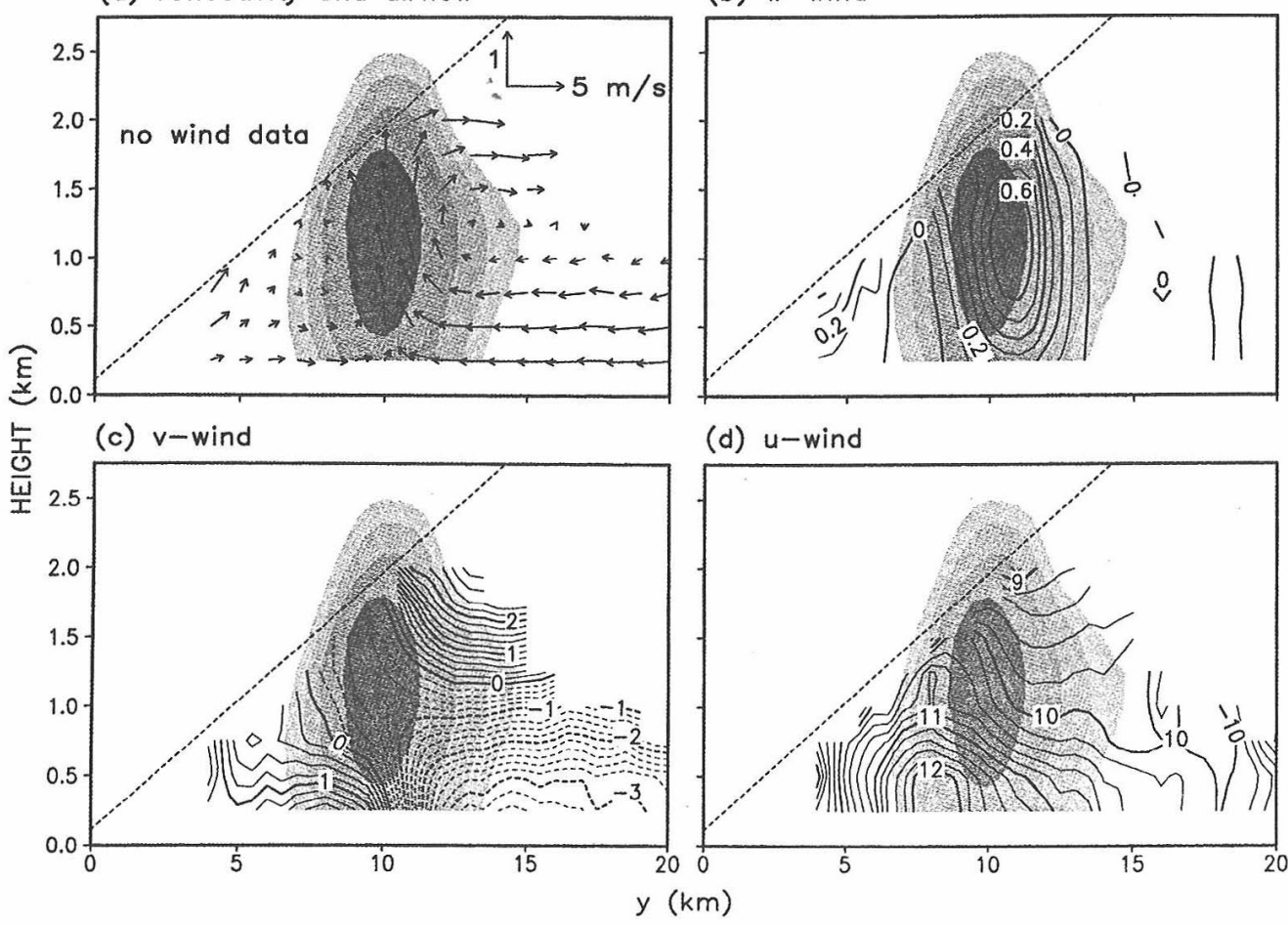

(d) u-wind
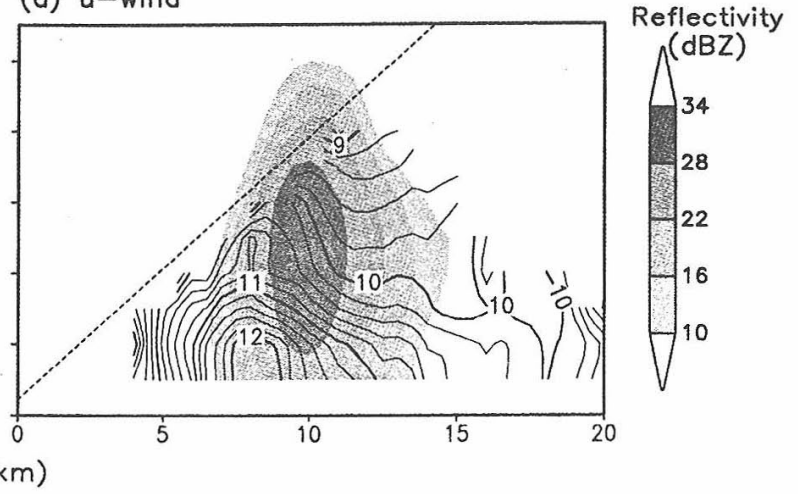

Fig. 8. As for Fig. 7 except that mean structure of the developed region of band II in a vertical cross section $(x=0 \mathrm{~km})$ perpendicular to the band axis is shown.

time (depicted by wide arrows). 'This indicates that the rapid development of clouds has occurred in this region. It should be noted that high reflectivity (exceeding $28 \mathrm{dBZ}$ ) regions descended with time in spite of the strong updrafts, for example, $x=-14$ to $-9 \mathrm{~km}$ at $1255 \mathrm{LST}$, and $x=-14$ to $-11 \mathrm{~km}$ at $1301 \mathrm{LST}$ (depicted by broken line). It was estimated from the vertical cross sections that at an altitude of $1.0 \mathrm{~km}$ (the cloud-base height) the updrafts had an average speed of about $1 \mathrm{~m} \mathrm{~s}^{-1}$ and the 28 $\mathrm{dBZ}$ contours of reflectivity descended at an average speed of about $2 \mathrm{~m} \mathrm{~s}^{-1}$. It is suggested from these estimations that large ice particles with a fall speed of about $3 \mathrm{~m} \mathrm{~s}^{-1}$ consisted the high-reflectivity regions. Since most of the snowflakes had fall speeds less than $2 \mathrm{~m} \mathrm{~s}^{-1}$ (e.g., Ishizaka 1995; Kajikawa et al. 1996), a large amount of graupel probably consisted the high-reflectivity regions of band II.

It is concluded that the intensifying and developed regions of band II had the airflow structure dominated by the circulations in the vertical cross sections perpendicular to the band axis. This airflow structure did not change with time qualitatively, and made the quasi-steady high-reflectivity zone of band II. The intensifying and developed regions of band II had quite different airflow structures from the meso$\gamma$-scale convective cloud systems composing band I, which had the three-dimensional airflow structure organized by strong band-parallel winds (reported in Part I).

\section{Airflows in the region between the two snowbands}

Figure 13 shows the time series of horizontal reflectivity patterns of the two snowbands at an altitude of $0.25 \mathrm{~km}$. The area shown in Fig. 13 corresponds with that outlined by dot-dashed line in Fig. 2. It should be noted that some radar echoes with reflectivities less than $10 \mathrm{dBZ}$ appeared between the two snowbands, which are depicted by circles in Fig. 13. This paper will refer to the radar echoes connecting the two snowbands as "radar-echo bridges." In this section, airflows in the region between the two snowbands will be examined.

Figure 14 shows the time series of horizontal reflectivity and storm-relative airflow patterns of the two snowbands at an altitude of $0.5 \mathrm{~km}$. The area shown in Fig. 14 corresponds with the area outlined by the broken line in Fig. 2. It should be noted that there were wind data in several regions between the two snowbands (for example, $x \approx-8 \mathrm{~km}$ at $1231 \mathrm{LST}, x \approx-5 \mathrm{~km}$ at $1255 \mathrm{LST}, x \approx-7 \mathrm{~km}$ at $1307 \mathrm{LST}$ and $x \approx-12 \mathrm{~km}$ at $1313 \mathrm{LST}$ ). This indicates that there were some radar-echo bridges between the two snowbands. In the radar-echo bridges, strong winds blew from band I toward band II. At 
Band $\|$ HEIGHT $=1.25 \mathrm{~km}$

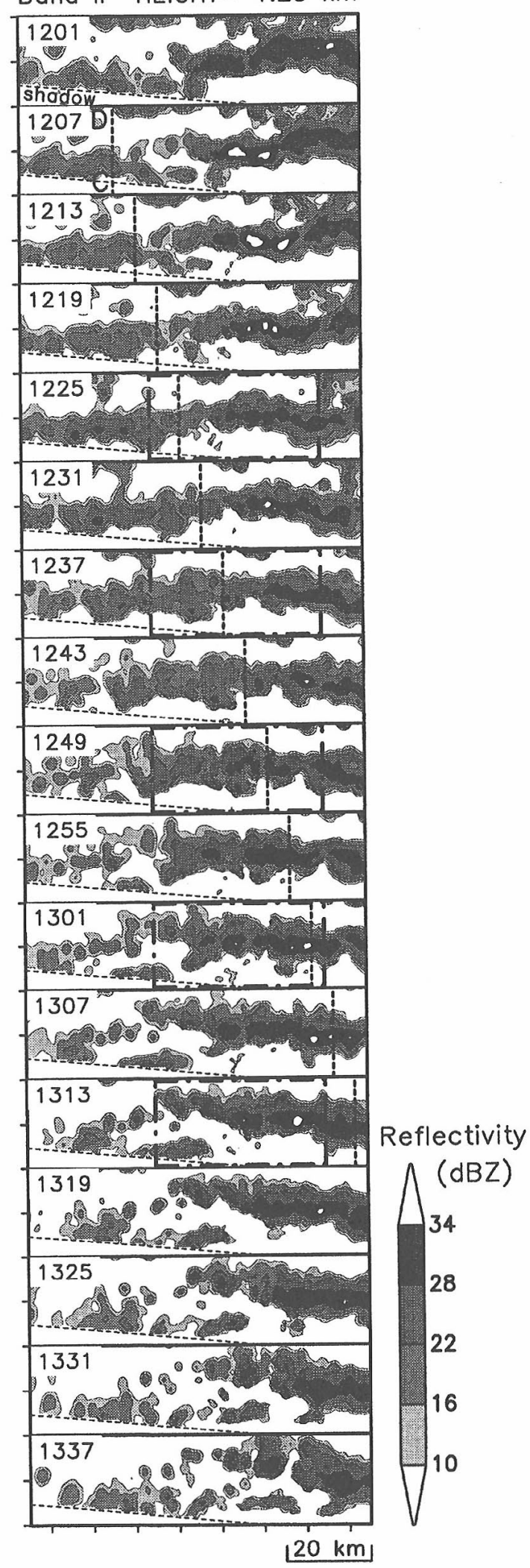

Fig. 9. Time series of radar reflectivity patterns of band II at an altitude of $1.25 \mathrm{~km}$. The region displayed in this figure is the box outlined by the dotted line in Fig. 2. The boxes outlined by the dot-dashed lines correspond with the radar display area shown in Fig. 11. The vertical broken line $C D$ shows the line along which the vertical cross sections first appeared in Fig. 10. In the first panel, the region below the thin broken line (labeled shadow) indicates the region in which the collection of radar data was prevented by the terrain. 


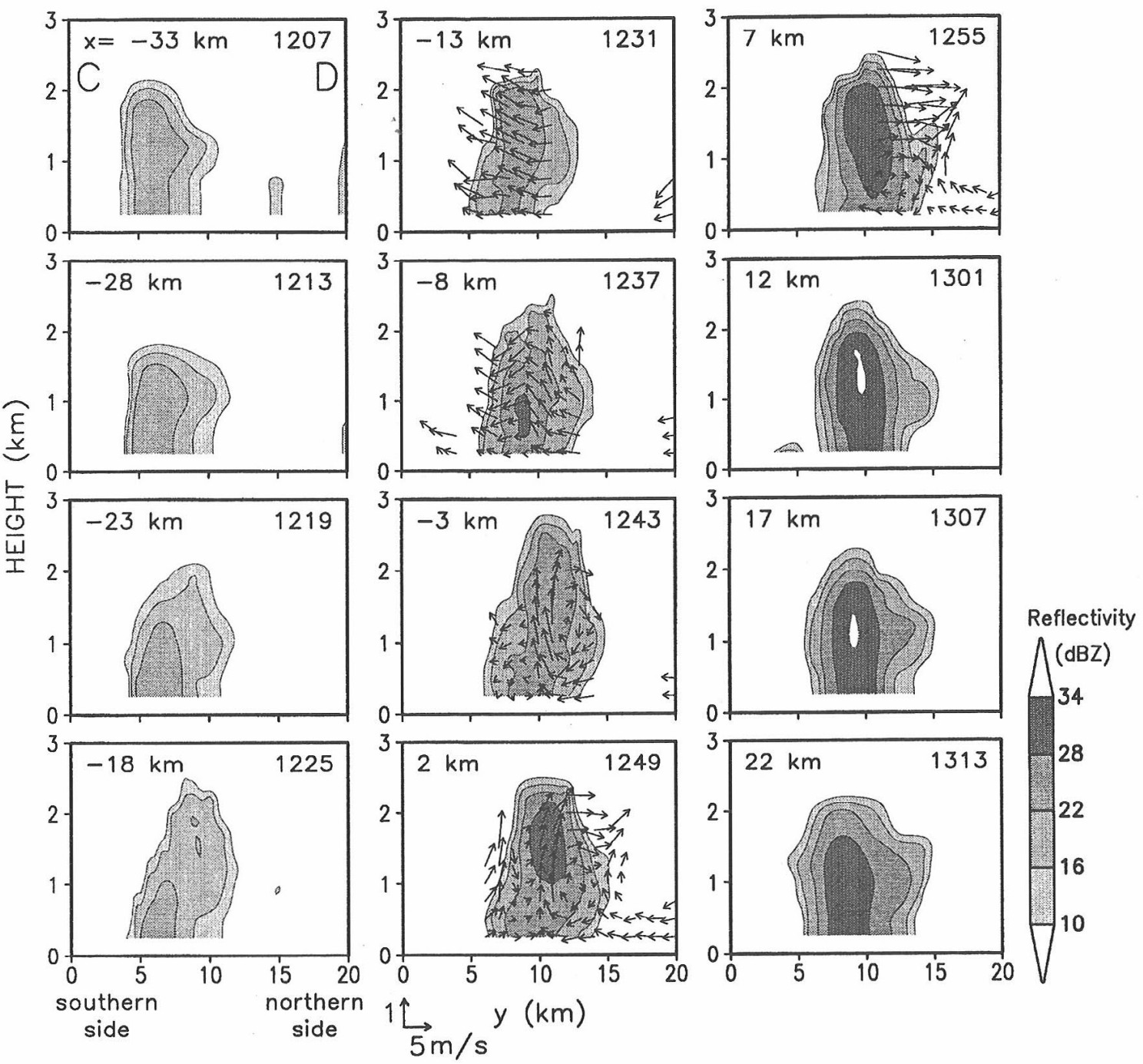

Fig. 10. Time series of radar reflectivities and airflows of band II in vertical cross sections perpendicular to the band axis. The vertical cross section in the first panel is along the vertical broken line $C D$ in Fig. 9.

1231 LST, strong winds blowing from band I toward band II were found at $x=-10$ to $-3 \mathrm{~km}$, $y \approx 15 \mathrm{~km}$. The maximum speed of the strong winds was $5 \mathrm{~m} \mathrm{~s}^{-1}$. In Fig. 14, the regions outlined by broken lines show the regions of winds having $u$ larger than the mean speed of cellular radar echoes $\left(12.5 \mathrm{~m} \mathrm{~s}^{-1}\right)$. These winds were referred to as rear-to-front currents in Part I. The strong winds blowing from band I toward band II were coming from a high-reflectivity (exceeding $22 \mathrm{dBZ}$ ) region of a meso- $\gamma$-scale system (meso 2) composing band I ( $x=-12$ to $-3 \mathrm{~km}, y=18$ to $22 \mathrm{~km}$ at $1231 \mathrm{LST})$. It is found that the rear-to-front current existed in the high-reflectivity region of meso $2(x=-1 \mathrm{~km}$, $y=22 \mathrm{~km}$ at $1237 \mathrm{LST}$ ). At $1243 \mathrm{LST}$, it is clear that the strong winds blowing from band I toward band II were coming from the region of rear-to-front current in meso 2 ( $x=-2$ to $7 \mathrm{~km}, y=20$ to $24 \mathrm{~km}$ ).

Figure 15 shows the time series of vertical wind velocities of the two snowbands at an altitude of $1.0 \mathrm{~km}$. The horizontal storm-relative airflows and the $10-\mathrm{dBZ}$ contours of reflectivity at an altitude of $0.5 \mathrm{~km}$ are also shown. This figure indicates that the strong winds blowing from band I toward band II were coming from a downdraft region of meso 2 in band $\mathrm{I}(x=-12$ to $-3 \mathrm{~km}, y=18$ to $22 \mathrm{~km}$ at $1231 \mathrm{LST}$ ). As revealed in Part I, rear-to-front currents were formed in the upper-north-rear of the meso- $\gamma$-scale convective cloud systems composing band I. Increasing in speed and volume, the rear-tofront currents descended toward the front and south of the meso- $\gamma$-scale convective cloud systems at the low levels. From these facts, the strong winds blowing from band I toward band II could be regarded as low-level outflows associated with the rear-to-front currents in the meso- $\gamma$-scale convective cloud systems composing band I. Other strong winds blowing from band I toward band II were found at $x=-5$ 
Band II

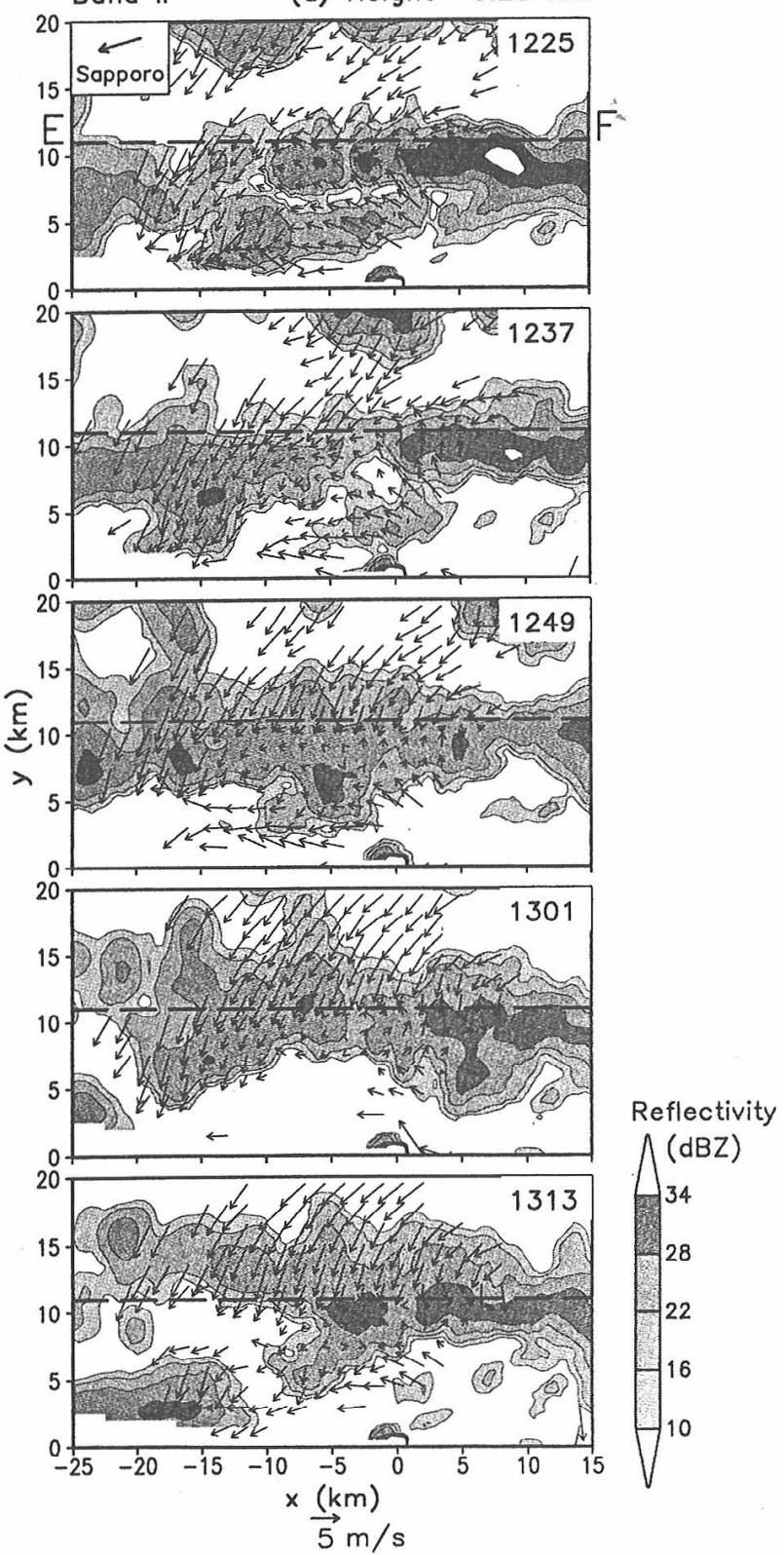

Band II $\quad$ (b) Height $=1.25 \mathrm{~km}$
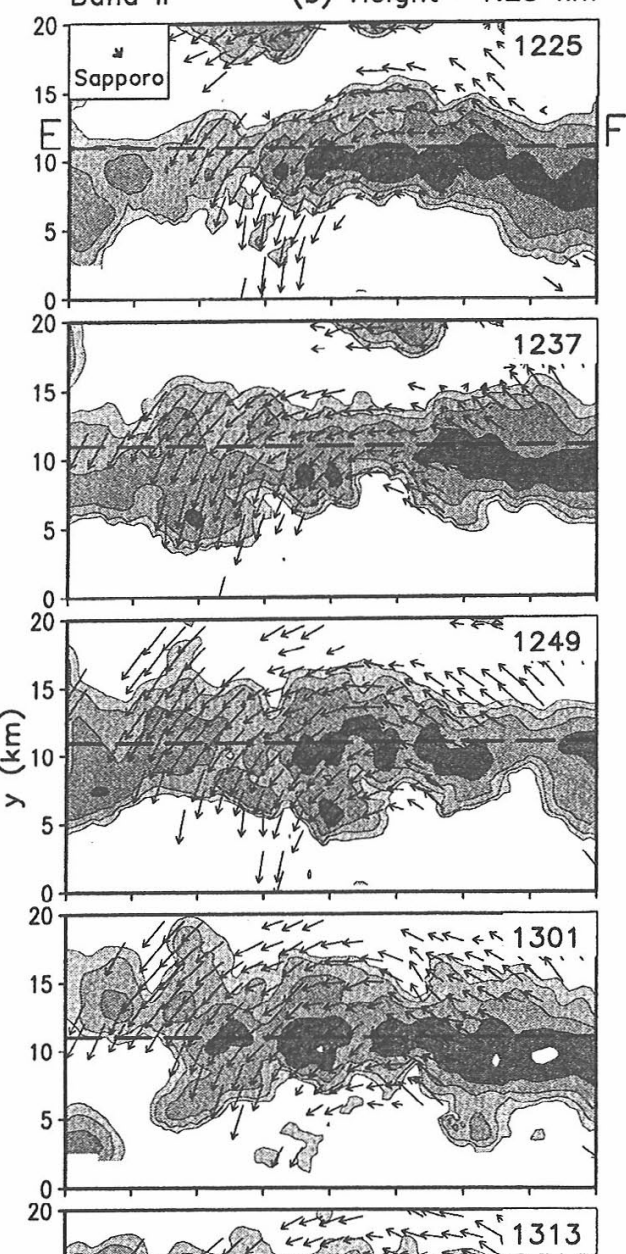

15

10.

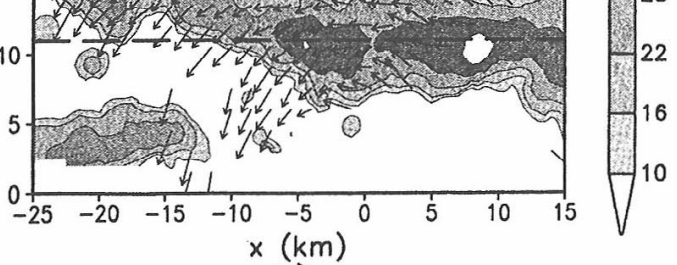

$\overrightarrow{5} \mathrm{~m} / \mathrm{s}$
Reflectivity

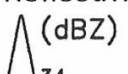

Fig. 11. Time series of radar reflectivities and storm-relative airflows in horizontal cross sections of the intensifying and developed regions of band II. (a) an altitude of $0.25 \mathrm{~km}$. (b) an altitude of $1.25 \mathrm{~km}$. (c) an altitude of $2.0 \mathrm{~km}$. The regions displayed in this figure are the boxes outlined by the dot-dashed lines in Fig. 9. The upper-air sounding data observed at Sapporo (the averages of winds observed at 0900 and 1500 LST) are also shown in the upper left of each panel. The horizontal broken line $E F$ shows the line along which the vertical cross sections first appeared in Fig. 12.

to $0 \mathrm{~km}, y=15$ to $20 \mathrm{~km}$ at 1255 LST (Figs. 14 and 15). These winds were coming from the highreflectivity and downdraft region of meso 3 in band I $(x=-5$ to $0 \mathrm{~km}, y=22$ to $25 \mathrm{~km}$ at $1255 \mathrm{LST})$.

Figure 16a shows the time series of the vertical cross section along the broken line $G H$ in Figs. 14 and 15 . This cross section was chosen to cut parallel to the low-level winds between the two snowbands. The place of the vertical cross section was made in phase with the cellular radar echoes composing the two snowbands. Figure 16a clearly shows the appearance and evolution of the strong winds blowing from band I toward band II. In the first panel, there were no wind data between the two snowbands, indicating that there were no ice/snow particles to be detected by the Doppler radars. At 1231 LST, however, strong winds blowing from band I toward band II (depicted by a long arrow) appeared in the southern outside of band I at the low levels (see also Fig. 14). It can be seen that the velocities of winds 


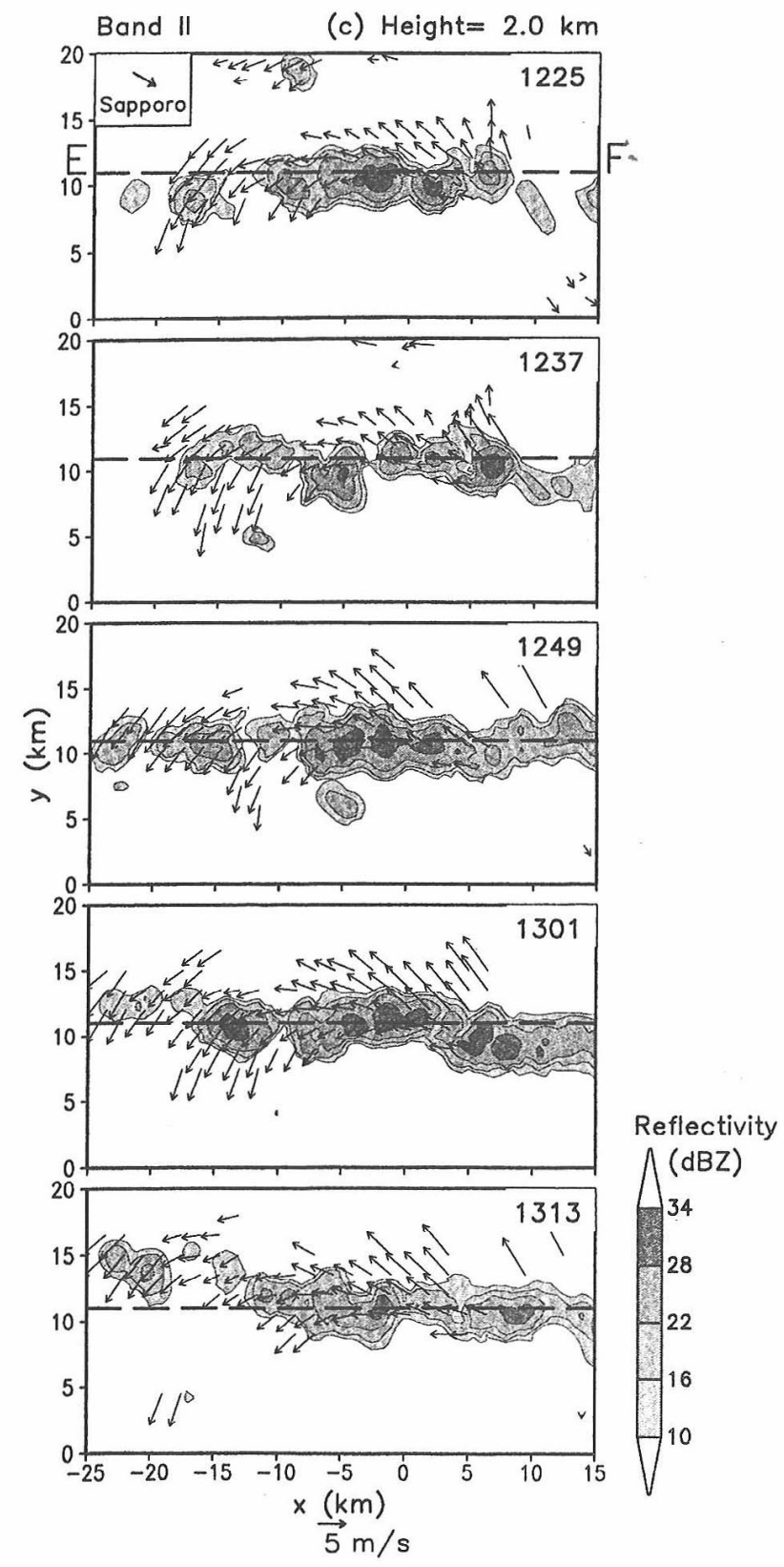

Fig. 11. (Continued)

in the southern outside of band I at the low levels were grater than those in band I. In the leading edge of the strong winds blowing band I toward band II, the velocities of winds reached $5 \mathrm{~m} \mathrm{~s}^{-1}$. At 1237 LST, wind data filled the region between the two snowbands at the low levels, indicating the formation of the radar-echo bridge between the two snowbands. The maximum height of the radarecho bridge was $750 \mathrm{~m}$. The leading edge of the strong winds blowing from band I toward band II (depicted by broken lines) moved toward band II with time. This arrived at the central part of band II at 1249 LST. Strong low-level convergence and the enhancement of updrafts occurred in the cen- tral part of band II. They were also seen in Fig. 15. The enhanced updrafts exceeding $1 \mathrm{~m} \mathrm{~s}^{-1}$ existed at $x \approx 3 \mathrm{~km}, y \approx 10 \mathrm{~km}$ at $1249 \mathrm{LST}$ in Fig. 15 . At $1301 \mathrm{LST}$, a high-reflectivity (exceeding $34 \mathrm{dBZ}$ ) region appeared in the central part of band II at the middle levels (Fig. 16a). The radar-echo bridge was maintained at least for 18 minutes (from 1237 LST to $1255 \mathrm{LST}$ ). Figure $16 \mathrm{~b}$ shows the time series of the vertical cross section along the dot-dashed line $I J$ in Figs. 14 and 15 . The similar features of radar echoes and airflows seen in Fig. 16a were also found in Fig. 16b. At 1243 LST, there were no wind data between the two snowbands. At 1249 LST, however, radar echoes with strong winds blowing from band I toward band II (depicted by a long arrow) appeared in the south of band I at the low levels. The maximum height of radar echoes was $750 \mathrm{~m}$. Figure 16b shows that the strong winds blowing from band I toward band II were coming from the high-reflectivity (exceeding $22 \mathrm{dBZ}$ ), and downdraft region of band I (as seen in Figs. 14 and 15). The leading edge of the strong winds blowing from band I toward band II (depicted by broken lines) moved toward band II with time. At $1255 \mathrm{LST}$, it is clear that wedgeshaped radar echoes (depicted by a wide arrow) existed in the southern edge of band I at the low levels, indicating clearly the existence of low-level outflows. At $1301 \mathrm{LST}$, the leading edge of the strong winds blowing from band I toward band II arrived at the central part of band II. Strong low-level convergence and the enhancement of updrafts occurred there. Figure 15 shows that the enhanced updrafts exceeding $1 \mathrm{~m} \mathrm{~s}^{-1}$ existed at $x \approx 0 \mathrm{~km}, y \approx 11 \mathrm{~km}$ at $1301 \mathrm{LST}$. At $1307 \mathrm{LST}$, the maximum updraft in band II reached a speed of $2 \mathrm{~m} \mathrm{~s}^{-1}$. High-reflectivity (exceeding $34 \mathrm{dBZ}$ ) region appeared in the central part of band II at the middle levels (Fig. 16b). It is clear that the upper-level outflows blowing from band II toward band I were enhanced, indicating that in this vertical cross section the circulations in band II were enhanced. The radar-echo bridge was maintained at least for 24 minutes (from 1249 LST to $1313 \mathrm{LST}$ ).

The appearance and evolution of the strong winds blowing from band I toward band II can be summarized as follows. The strong winds blowing from band I toward band II began to appear in the south of the high-reflectivity and downdraft regions of the meso- $\gamma$-scale convective cloud systems composing band I at the low levels. The winds corresponded to the low-level outflows associated with rear-to-front currents in the meso- $\gamma$-scale convective cloud systems composing band I. The leading edges of the strong winds blowing from band I toward band II moved toward band II with time, and penetrated into band II. Strong low-level convergence and the enhancement of the updrafts occurred in the central part of band II. Then, strong radar echoes appeared 


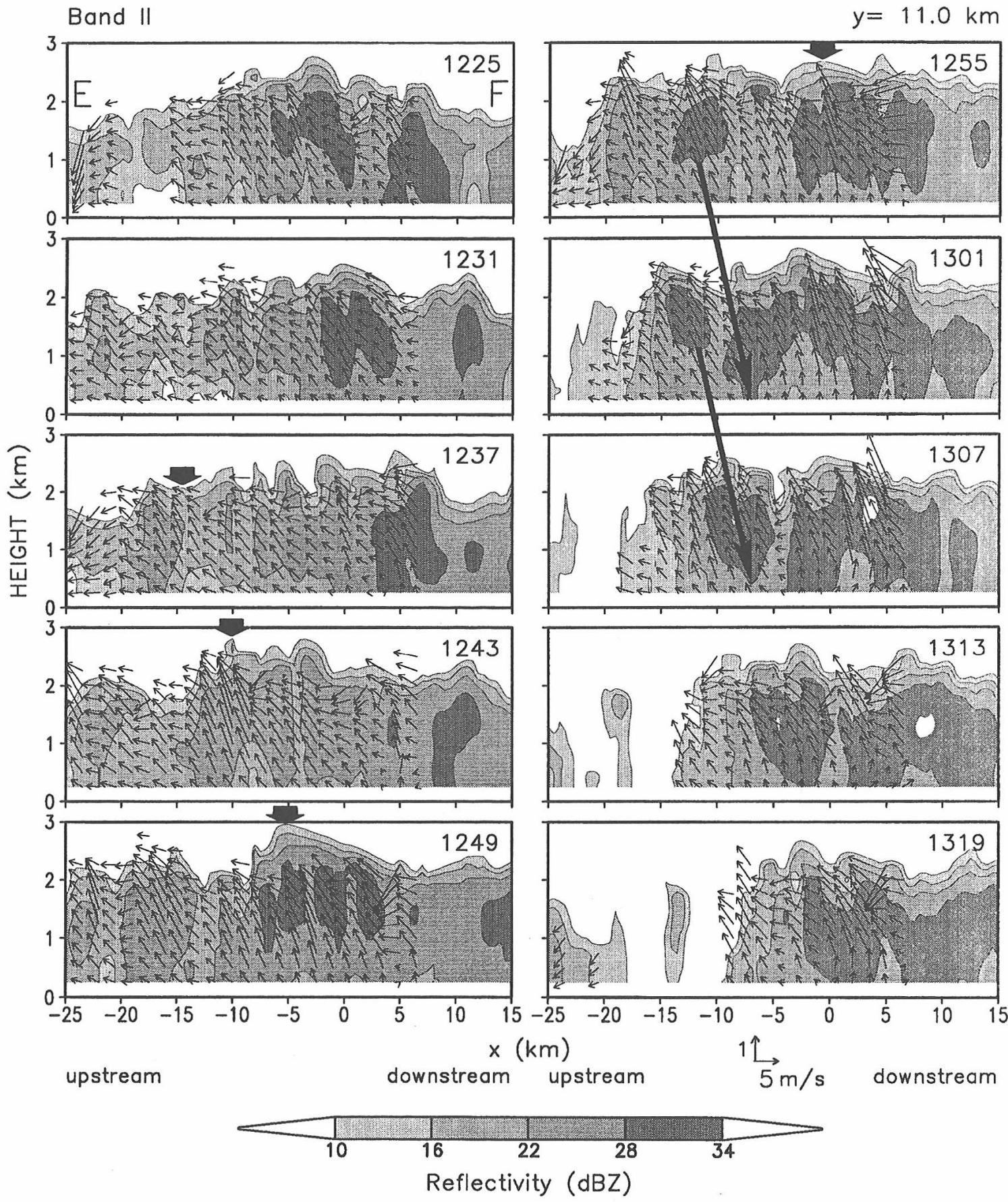

Fig. 12. Time series of radar reflectivities and storm-relative airflows of the intensifying and developed regions of band II in vertical cross sections parallel to the band axis. The vertical cross section in the first panel is along the horizontal broken line $E F$ in Fig. 11.

in the central part of band II at the middle levels. These phenomena were commonly observed in the other several regions between the two snowbands. The relationship between the strong winds blowing from band I toward band II, and the formation of the strong radar echoes in band II, will be discussed in the next section.

\section{Discussion}

\subsection{Modification of band II over the Ishikari Bay}

As seen in Fig. 3, band II was formed off the west of the Ishikari Bay. As shown in Fig. 9, the radar-echo structure of the upstream region of band II was similar to that of band I, that is, the cellular radar echoes were aligned with the band axis at a nearly regular interval. Off the west of the 

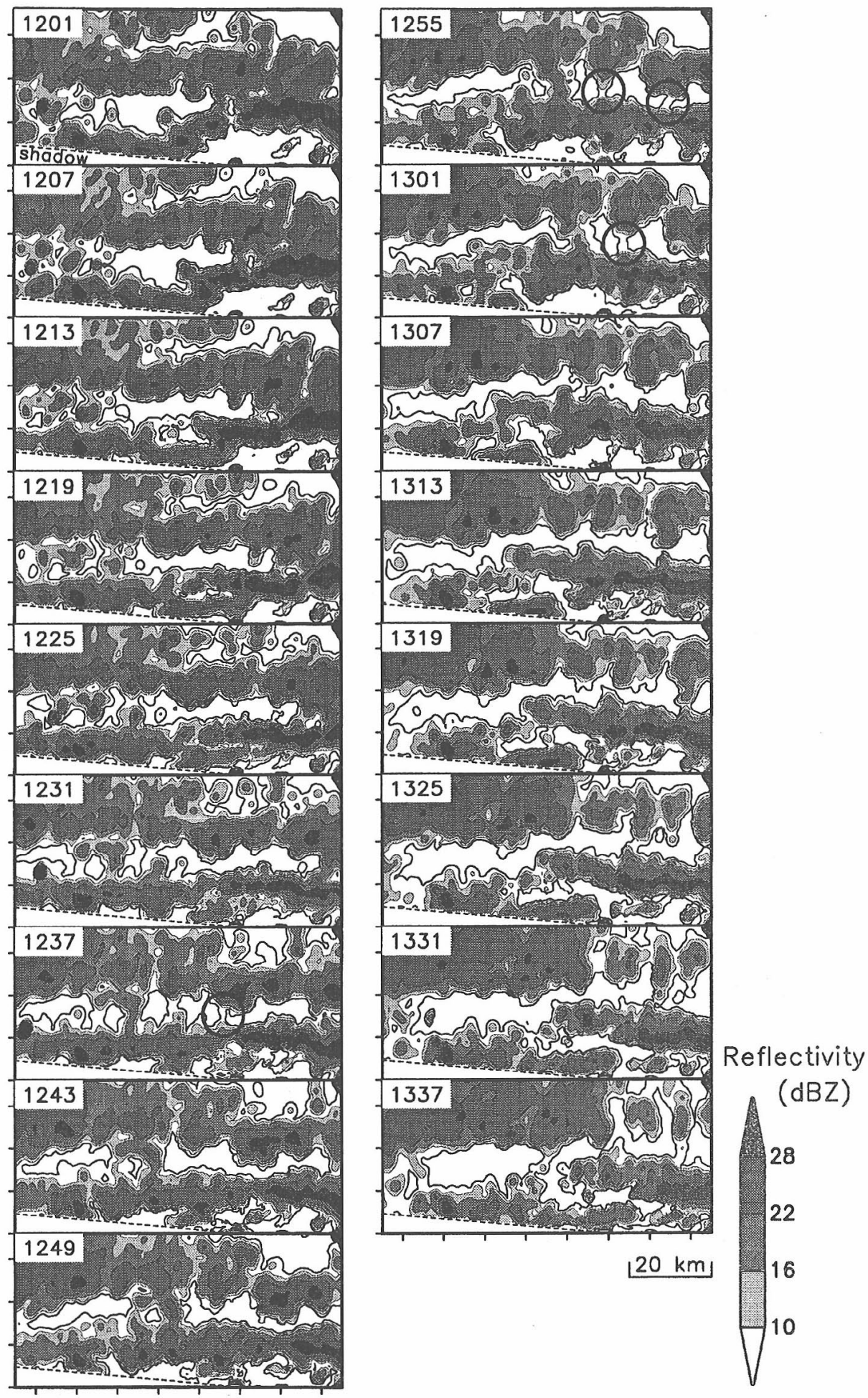

Fig. 13. Time series of radar reflectivity patterns of the two snowbands at an altitude of $0.25 \mathrm{~km}$. The region displayed in this figure is the box outlined by the dot-dashed line in Fig. 2. The thick contours show a reflectivity of $0 \mathrm{dBZ}$. In the first panel, the region below the thin broken line (labeled shadow) indicates the region in which the collection of radar data was prevented by the terrain.

Ishikari Bay, band II could be regarded as one of typical longitudinal-mode snowbands appearing over the Sea of Japan. However, the radar-echo structure of band II noticeably changed over the Ishikari
Bay as seen in Fig. 9. Since the quasi-steady highreflectivity zone of band II existed over the Ishikari Bay (Fig. 9), the development of band II probably have been related with the topography around the 


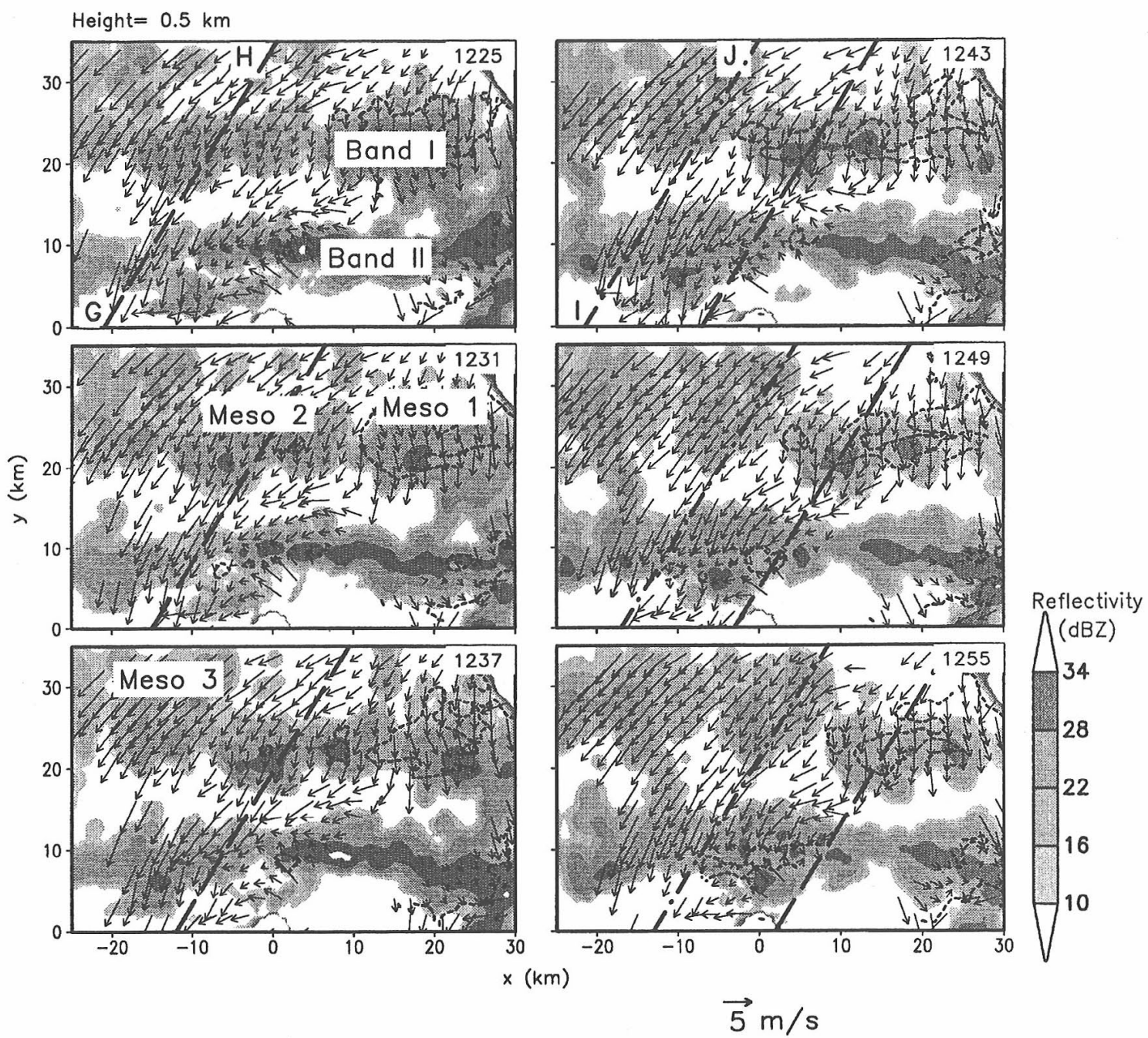

Fig. 14. Time series of radar reflectivities and storm-relative airflows in horizontal cross sections of the two snowbands at an altitude of $0.5 \mathrm{~km}$. The region displayed in this figure is the box outlined by the broken line in Fig. 2. The regions outlined by broken lines shows the regions of winds having $u$ larger than the mean speed of cellular radar echoes $\left(12.5 \mathrm{~m} \mathrm{~s}^{-1}\right)$. The broken line $G H$ shows the line along which the vertical cross sections first appear in Fig. 16a. The dot-dashed line $I J$ shows the line along which the vertical cross sections first appear in Fig. 16b.

Ishikari Bay.

Kikuchi et al. (1987) numerically simulated the horizontal wind fields over the Ishikari Bay using a Lavoie's (1972) mesoscale model. The results showed that the winds in the northern part of the Shakotan Peninsula blew more westerly than those in the other regions of the Ishikari Bay. They explained the eastward motion of radar echoes near the northern part of the Shakotan Peninsula by the westerly winds rounding the Shakotan Peninsula. In the present case, the cellular radar echoes near the northern part of the Shakotan Peninsula have moved from more west (about $10^{\circ}$ ) than the other cellular radar echoes over the Ishikari Bay (not shown). The horizontal wind fields derived by the dual-Doppler radars showed that at the lowest level the winds in the southern side of band II did not agree with the upper-air sounding data (Fig. 11a). Figure 17 shows horizontal cross sections of radar reflectivities and ground relative airflows in the intensifying and developed regions of band II at an altitude of $0.25 \mathrm{~km}$. In the northern side of band II the winds blew from the west-northwest or the northwest. In the southern side of band II, however, the winds blew from the west. Therefore, the westerly winds in the southern side of band II at the lowest level would have corresponded to the winds rounding the Shakotan Peninsula. The changes in the motions of cellular radar echoes near the northern part of the Shakotan Peninsula would have been attributed to the airflows rounding the mountains in the Shakotan Peninsula. According to the aforementioned discus- 

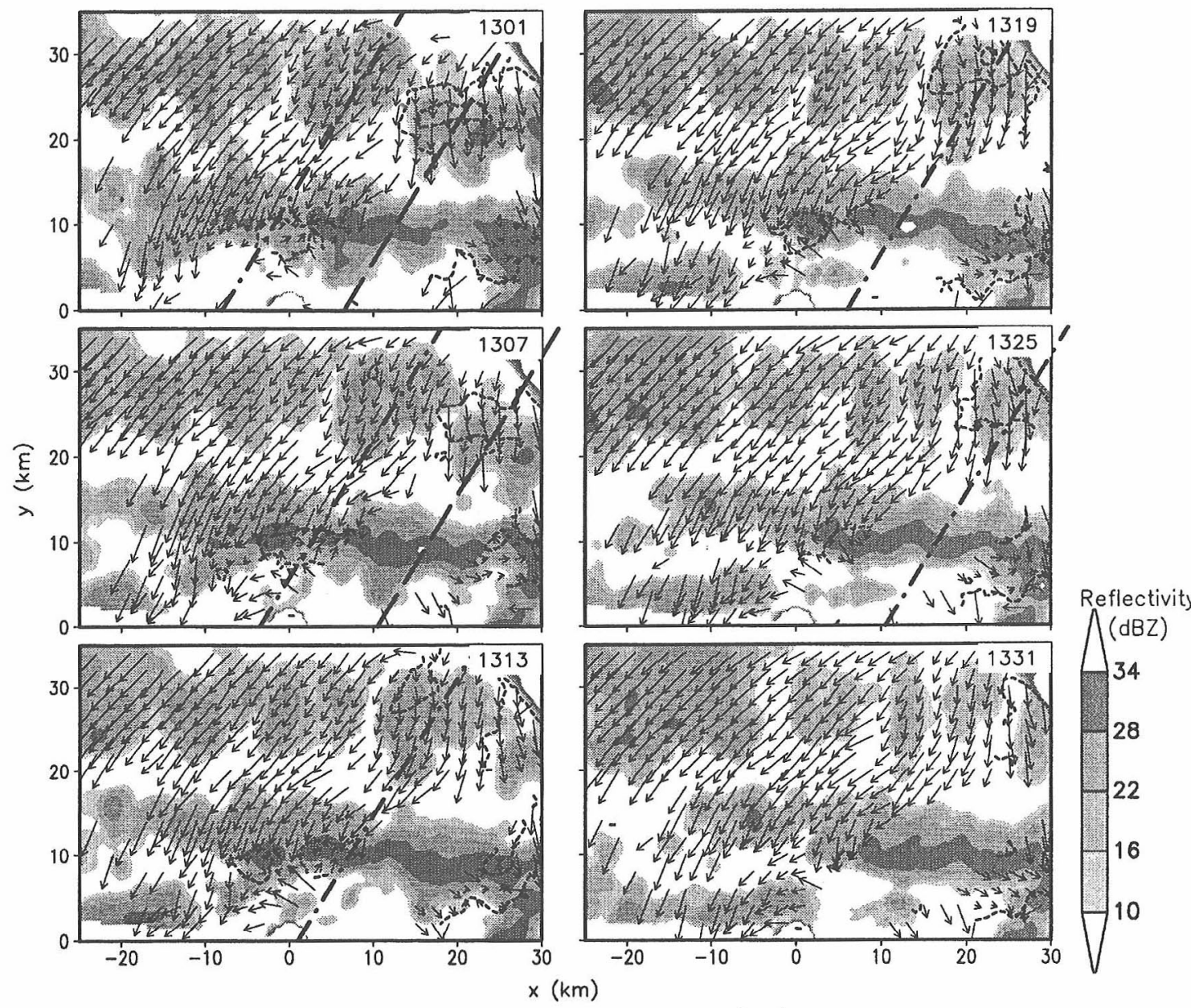

$$
\overrightarrow{5} \mathrm{~m} / \mathrm{s}
$$

Fig. 14. (Continued)

sions, it is considered that the encounters between the west-northwesterly winds corresponding to the winter monsoon and the westerly winds rounding the Shakotan Peninsula occurred over the Ishikari Bay and caused the modification of band II over the Ishikari Bay. Further discussions on the influence of the topography around the Ishikari Bay on the development of snowbands will be reported in a forthcoming paper using three-dimensional numerical model.

\subsection{Relationship between the low-level outflows from band $I$, and the development of band II}

Figure 18 shows temporal changes of the snow waters of band II and the horizontal mass transports coming into band II at an altitude of $0.25 \mathrm{~km}$. The horizontal mass transports perpendicular to the band axis were calculated in the northern edges, which were defined by the radar-echo boundaries of $10 \mathrm{dBZ}$, of band II. It should be noted that the snow water of band II noticeably increased from $1243 \mathrm{LST}$ to 1307 LST, indicating the development of band II.
The horizontal mass transports from the northern edge of band II rapidly increased with time from 1231 LST due to the penetration of the strong winds from band I. The low-level environmental winds in the northern outside of band I changed little with time during the period of analysis (Fig. 14). Therefore, it is concluded that the noticeable increase of the snow water of band II observed between 1243 and 1307 LST was attributed to the penetration of the strong winds from band I. Although the large values of the horizontal mass transports were maintained between 1249 LST and 1337 LST, the snow water of band II decreased with time after 1307 LST. This could be explained by the penetration of weak radar-echoes from the upstream side after 1249 LST (Fig. 9).

Sakakibara et al. (1988), and Ishihara et al. (1989), observed that cold low-level outflows were formed in the snowbands. They suggested the lowlevel outflows from the snowbands would have been heated by the warm sea surface, and might have been destabilized before encountering the winter 

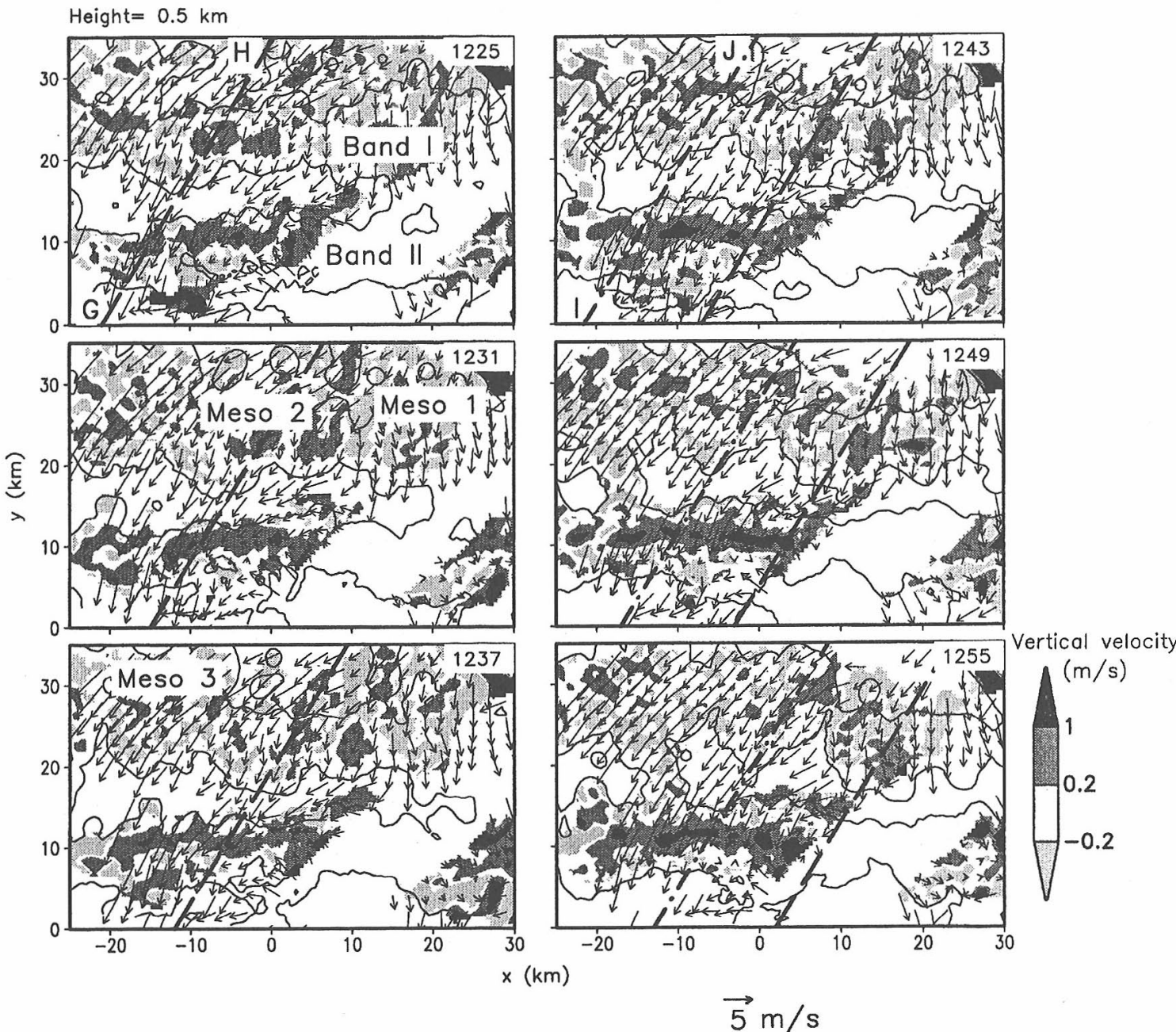

Fig. 15. Time series of vertical wind velocities of the two snowbands in horizontal cross sections at an altitude of $1.0 \mathrm{~km}$. The horizontal storm-relative airflows and the 10-dBZ contours of reflectivity at an altitude of $0.5 \mathrm{~km}$ are also shown. The region displayed in this figure is the box outlined by the broken line in Fig. 2. The broken line $G H$ shows the line along which the vertical cross sections first appear in Fig. 16b.

monsoon air. Since the rear-to-front currents in the meso- $\gamma$-scale systems composing band I were induced by the evaporation of ice/snow particles near the cloud top, it can be inferred that the low-level outflows associated the rear-to-front currents would have been colder than the environmental winds. The low-level outflows from band I would have been heated by the warm sea surface before penetrating into band II. Since the Shakotan Peninsula was covered by snow, the westerly winds in the south of band II passing over the Shakotan Peninsula would have been colder than the winds in the other regions of the Ishikari Bay. Therefore, it can be inferred that the winds coming from the northern side of band II would have supplied warm air into the updrafts in band II.

As seen in Fig. 14, several strong winds blow- ing from band I toward band II were found between the two snowbands. Since the alignment of the two snowbands was parallel to the mean wind in the mixed layer (see Fig. 8 in Part I), the strong winds blowing from band I toward band II repeatedly penetrated into band II over the Ishikari Bay (Figs. 14 and 16). Thus, the horizontal mass transports coming into band II at the lowest level maintained the large values after 1249 LST (Fig. 18). This contributed to the development of band II and the maintenance of the high-reflectivity zone of band II.

The strong winds blowing from band I transported ice/snow particles into band II. Since the reflectivities of radar-echo bridges between the two snowbands were less than $10 \mathrm{dBZ}$ (Figs. 13, 14, 15, and 16$)$, the radar-echo bridges were made by small 

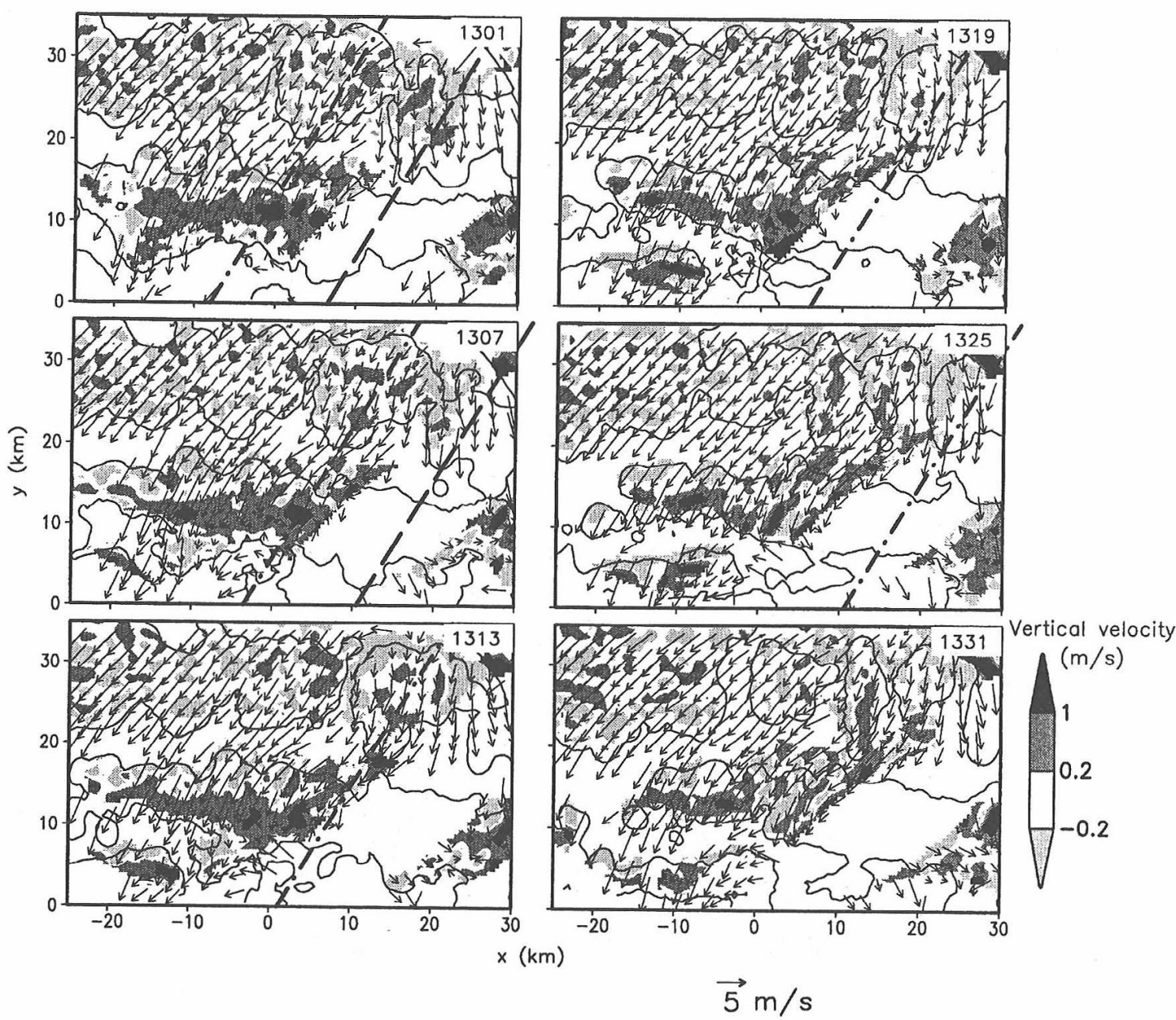

Fig. 15. (Continued)

ice/snow particles. Small ice/snow particles have small fall speeds (less than $1 \mathrm{~m} \mathrm{~s}^{-1}$ ). Thus, small ice/snow particles transported from band I into band II would have been lifted up into clouds composing band II by the enhanced updrafts $\left(2 \mathrm{~m} \mathrm{~s}^{-1}\right.$ at the maximum) and could grow rapidly through riming process (as suggested in Fig. 11). As these results, stronger radar echoes were formed in band II and band II rapidly developed.

Next, the spacing between snowbands will be discussed. In the present case, the spacing between the two snowbands was $5-10 \mathrm{~km}$. This value shows a typical value of longitudinal-mode snowbands observed over the Sea of Japan. If the spacing between snowbands is much larger than this value (for example, several tenth kilometers), ice/snow particles transported by low-level outflows from a snowband probably arrive at the sea surface before arriving at an adjacent snowband. Thus, it is considered that the action of ice/snow particles transported from a snowband on an adjacent snowband is an important feature that may occur in longitudinal-mode snowbands with small spacing.

\subsection{Difference of the structures between the two snowbands}

The intensifying and developed regions of band II had the airflow structure dominated by the circulations in the vertical cross sections perpendicular to the band axis. On the other hand, the meso$\gamma$-scale convective cloud systems composing band I had the three-dimensional airflow structures organized by strong band-parallel winds. The airflow structures were essentially different between the two snowbands. Two reasons could explain the large differences of the kinematic structures between the two snowbands: 1) the modification of band II due to the terrain and 2) the influence of the kinematics of band I on band II. The low-level outflows from band I penetrated into band II. They encountered winds coming from the south of band II at the low levels. Since the westerly winds in the south of band II at the low levels were induced and maintained by the terrain, the penetration of the low-level outflows could have caused the strong convergence and the enhancement of updrafts in band II.

In the present case, the interactions between the 


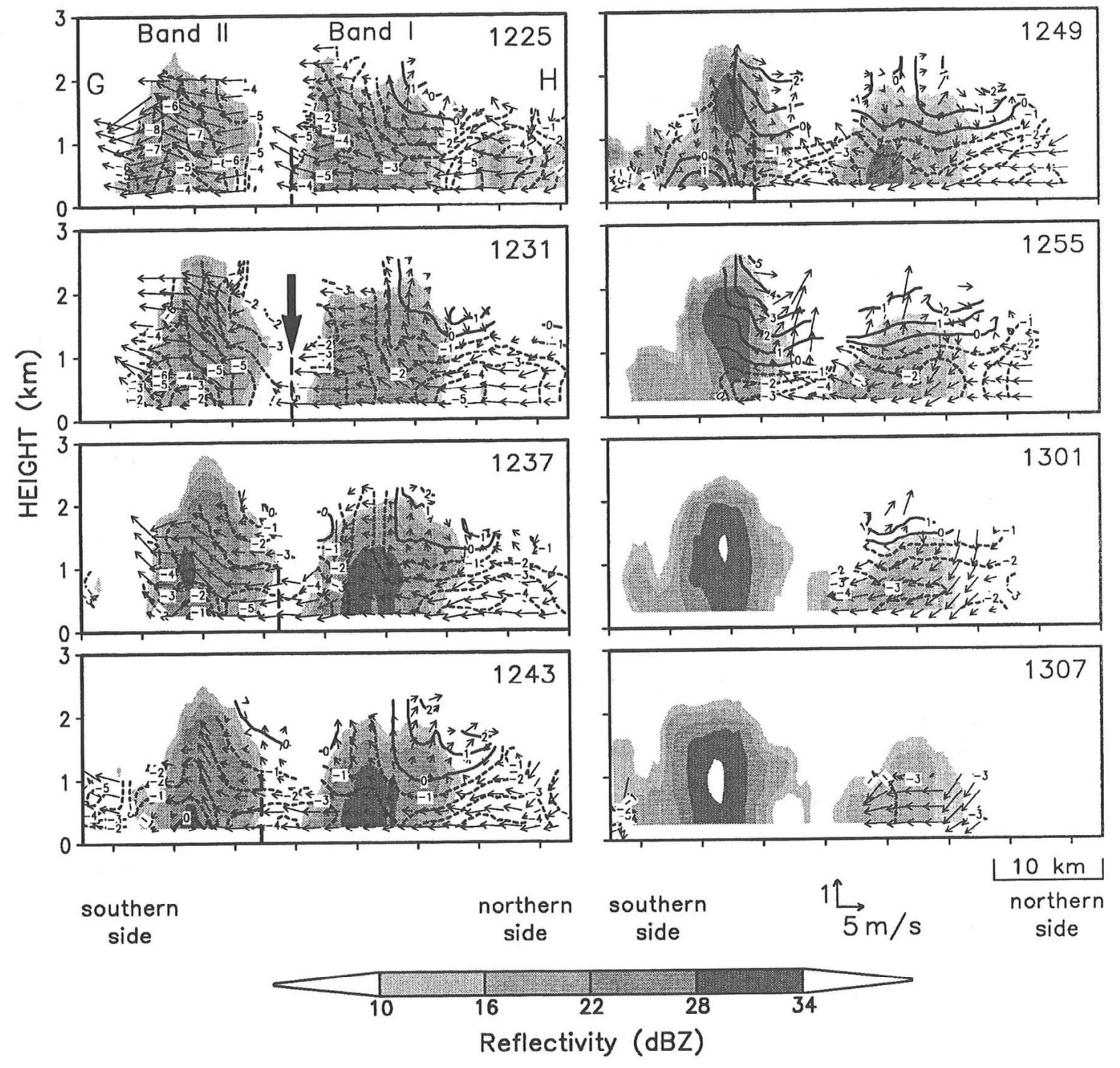

Fig. 16. Time series of radar reflectivities and storm-relative airflows of the two snowbands in vertical cross sections. Horizontal velocities parallel to the vertical cross sections are contoured every $1 \mathrm{~m} \mathrm{~s}^{-1}$. (a) The vertical cross section in the first panel is along the broken line $G H$ in Figs. 14 and 15. (b) The vertical cross section in the first panel is along the dot-dashed line $I J$ in Figs. 14 and 15.

two snowbands might have occurred already off the west of the Ishikari Bay. Since band II was modified over the Ishikari Bay by orographic effects, the influence of the kinematics of band I on band II would have appeared remarkably.

\section{Summary and conclusions}

Two longitudinal-mode snowbands (bands I and II) were observed over the Ishikari Bay, Hokkaido, Japan using a dual-Doppler radar system. In this paper, the three-dimensional kinematic structure of band II was examined in detail.

Band II noticeably developed over the Ishikari Bay. A high-reflectivity (exceeding $28 \mathrm{dBZ}$ ) zone along the band axis was formed over the Ishikari Bay and was maintained during the period of analysis.
This characterized the radar-echo structure of band II. From the radar-echo structures, band II could be separated to the three regions: that is, the upstream region, the intensifying region, and the developed region. The upstream region of band II showed the similar radar-echo structure as band I, that is, the cellular radar echoes were aligned with the band axis at a nearly regular interval. The intensifying and developed regions of band II had the airflow structure dominated by the circulations in the vertical cross sections perpendicular to the band axis. The airflow structures did not change with time qualitatively during the period of analysis. The kinematic structures of the intensifying and developed regions of band II were essentially different from those of the meso- $\gamma$-scale convective cloud systems compos- 


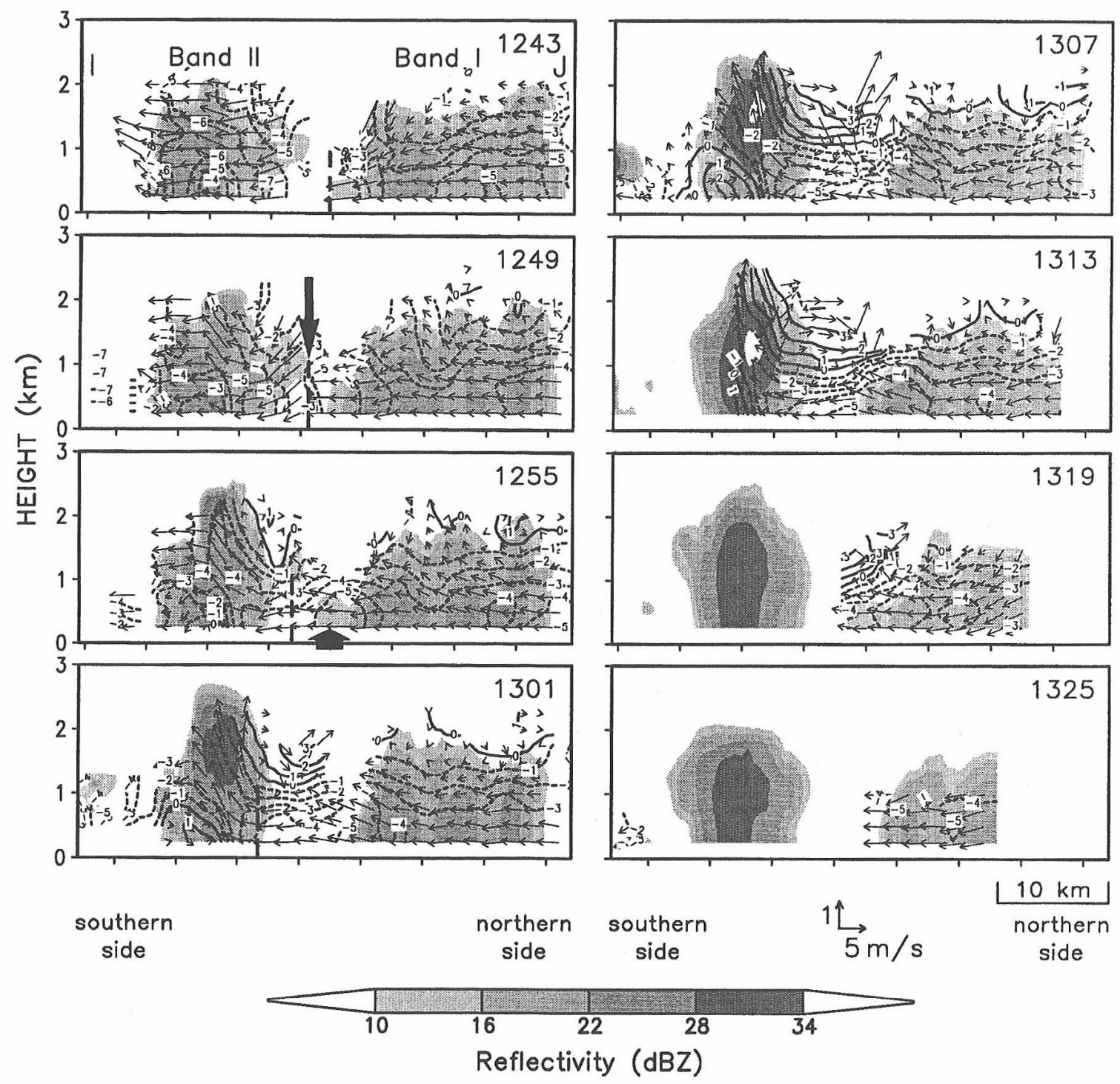

Fig. 16. (Continued)

ing band I. It was considered that the encounters between the west-northwesterly winds corresponding to the winter monsoon and the westerly winds rounding the Shakotan Peninsula occurred over the Ishikari Bay, and caused the modification of band II over the Ishikari Bay.

The interactions between the two snowbands were discussed. Interestingly, it was found that the radarecho bridges existed at the low levels between the two snowbands. The formation of the radar-echo bridges and the development of band II are schematically illustrated in Fig. 19. The rear-to-front currents were formed in the meso- $\gamma$-scale convective cloud systems composing band I. The rear-to-front currents arrived at the southern part of the meso$\gamma$-scale convective cloud systems at the low levels. This formed the low-level outflows blowing from band I toward band II (the top panel of Fig. 19). The low-level outflows moved toward band II with time and penetrated into band II. The low-level outflows transported ice/snow particles from band I into band II. This formed the radar-echo bridges between the two snowbands (the middle panel of Fig. 19). The low-level outflows encountered the winds coming from the southern outside of band II in the central part of band II. This caused strong low-level convergence and the enhancement of the updrafts in the central part of band II (the bottom panel of Fig. 19). Consequently, stronger radar echoes were formed in band II and band II rapidly developed. The ice/snow particles transported by the low-level outflows would have been lifted up into clouds composing band II by the enhanced updrafts. These particles could have grown rapidly through riming process. This would have contributed to the development of band II.

Although it should be noted that the modification of band II over the Ishikari Bay was related 


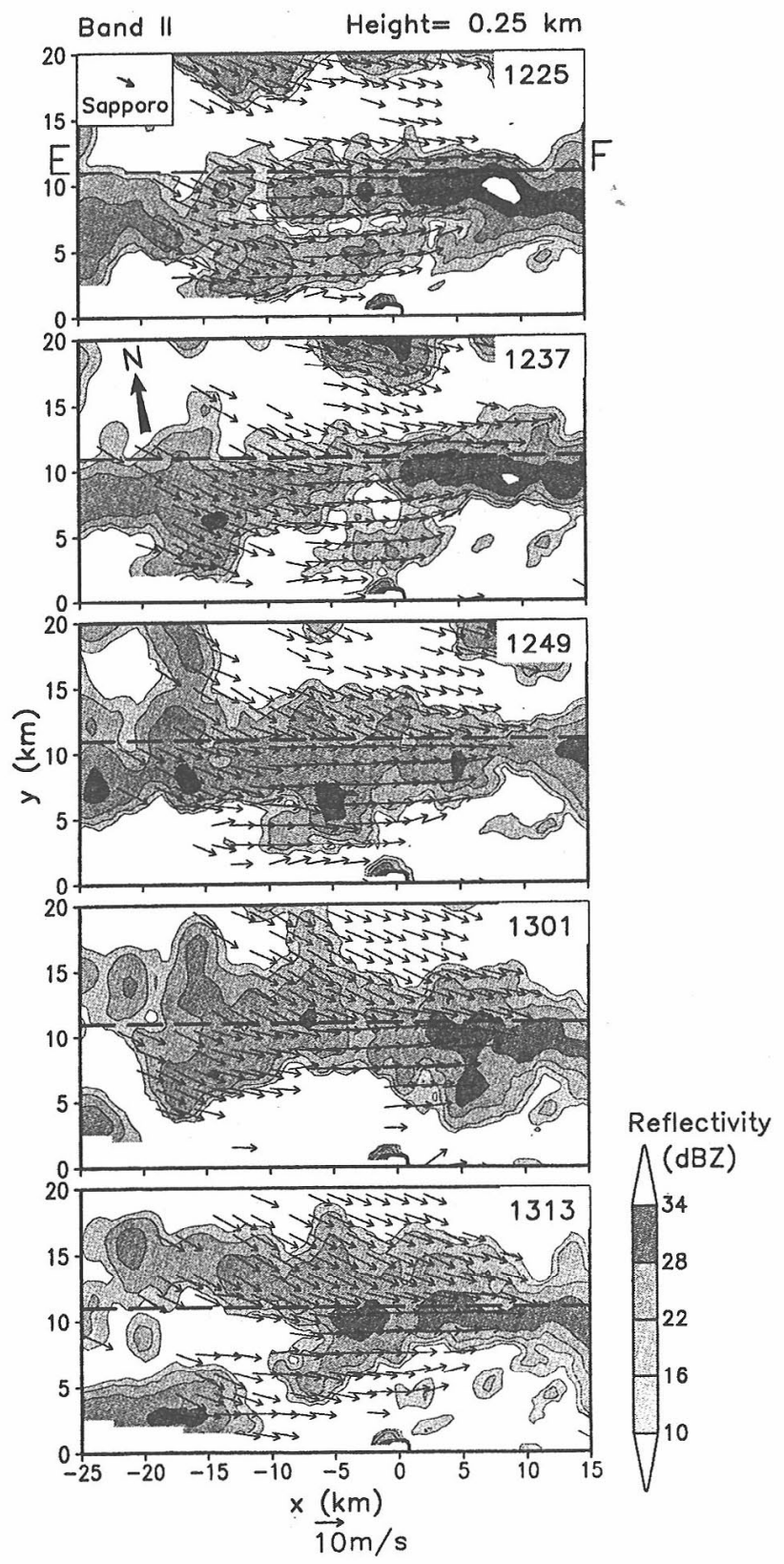

Fig. 17. As for Fig. 11a except that ground relative airflows are shown. The large arrow in the second panel shows the direction of north.

with orographic effects, the results presented in this paper strongly suggest that interactions between longitudinal-mode snowbands may cause essential differences in the airflow structures and the large differences of the snowfalls between longitudinal-mode snowbands. The influence of the kinematics of band II on band I could not be investigated due to the lack of wind data at the middle and upper levels between the two snowbands. The data used in this study restricted the range of discussion to the reflectivity and airflow ficlds. The thermodynamic structure of the low-level outflows from band I could not be discussed here in detail. It is interesting that the ice/snow particles generated in band I would have

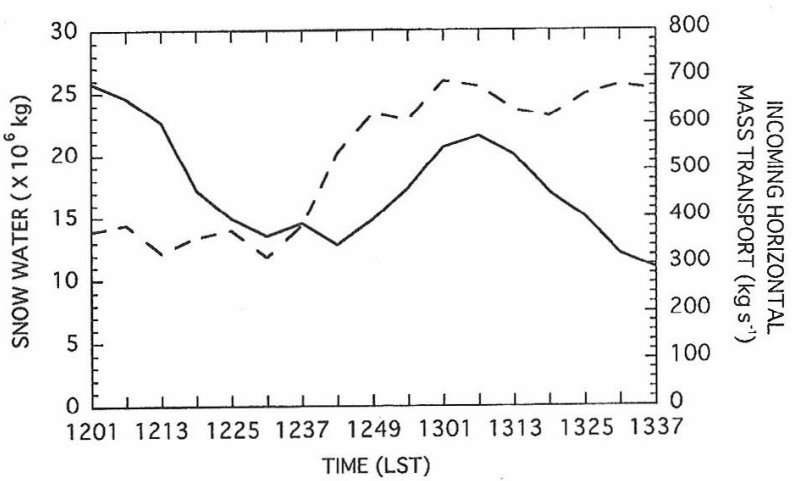

Fig. 18. Temporal changes of the snow waters of band II and the horizontal mass transports coming into band II at an altitude of $0.25 \mathrm{~km}$. The snow waters (solid line) were calculated on the basis of the radar-echo boundaries of $10 \mathrm{dBZ}$. The calculated region is $-20 \mathrm{~km} \leq x<20 \mathrm{~km}$. The horizontal mass transports perpendicular to the band axis (broken line) were calculated in the northern edge, which were defined by the radar-echo boundaries of $10 \mathrm{dBZ}$, of band II. The horizontal mass transports averaged in the region between $x=-5 \mathrm{~km}$ and $x=5 \mathrm{~km}$ are shown.
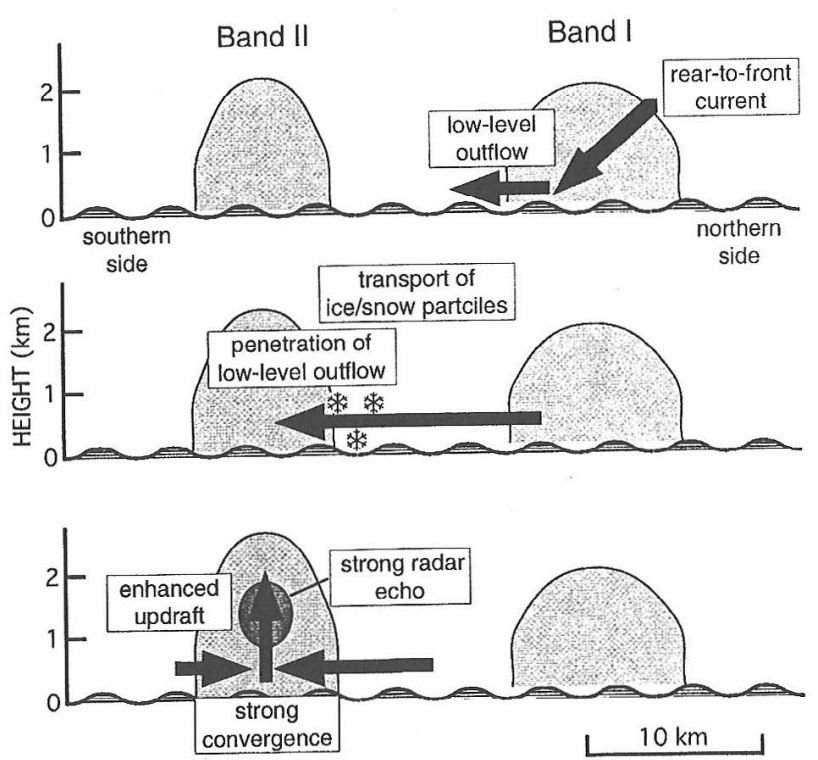

Fig. 19. Schematic pictures indicating the development of band II caused by the penetration of the low-level outflows from band I. Radar echoes and airflows in vertical cross sections perpendicular to the band axis are shown. The regions of reflectivities exceeding $10 \mathrm{dBZ}$ are stippled. The arrows show airflows. The wave lines show the sea surfaces. 
contributed to the development of band II. However, the characteristics of the ice/snow particles could not be discussed here due to the lack of microphysics data. To clarify the interactions between longitudinal-mode snowbands, the thermodynamics and microphysics in longitudinal-mode snowbands should be investigated. Cooperated studies with research aircraft and short-time-interval upper-air sounding are needed to make a further discussion of the process presented in this paper.

\section{Acknowledgments}

The authors are grateful to the Sapporo City Office and the Sapporo Information Network Company Limited for providing the data of the radar at Tobetsu. The authors express their hearty thanks to anonymous reviewers for their valuable comments. This research was supported by a Grant-in-Aid for Scientific Research from the Ministry of Education, Science, Sports, and Culture of Japan (A-4-2).

\section{References}

Asai, T., 1970: Three-dimensional features of thermal convection in a plane Couette flow. J. Meteor. Soc. Japan, 48, 18-29.

Asuma, Y. and K. Kikuchi, 1987: Snowfall properties in the Sapporo city area and the occurrence frequency of radar echoes over the Ishikari Bay, Hokkaido, Japan. Geophys. Bull. Hokkaido Univ., 49, 317-330 (in Japanese with English abstract).

Brown, R.A., 1970: A secondary flow model for the planetary boundary layer. J. Atmos. Sci., 27, 742-757.

Fujiyoshi, Y., K. Tsuboki, S. Satoh and G. Wakahama, 1992: Three-dimensional radar echo structure of a snow band formed on the lee side of a mountain. $J$. Meteor. Soc. Japan, 70, 11-24.

-, N. Yoshimoto and T. Takeda, 1998: A dualDoppler radar study of longitudinal-mode snowbands. Part I: A three-dimensional kinematic structure of meso- $\gamma$-scale convective cloud systems within a longitudinal-mode snowband. Mon. Wea. Rev., 126, 72-91.

Ishihara, M, H. Sakakibara and Z. Yanagisawa, 1989: Doppler radar analysis of the structure of mesoscale snow bands developed between the winter monsoon and the land breeze. J. Meteor. Soc. Japan, 67, 503520.

Ishizaka, M., 1995: Measurement of falling velocity of rimed snowflakes. Seppyo, 57, 229-238 (in Japanese with English abstract).

Kajikawa, M., S. Taniguchi and S. Ito, 1996: Relationship between the fall velocity of snowflakes and the shape of their component crystals. Seppyo, 58, 455462 (in Japanese with English abstract).

Kikuchi, K., S. Azumane, M. Murakami and T. Taniguchi, 1987: Precipitating snow clouds during winter monsoon seasons influenced by topography of the Shakotan Peninsula, Hokkaido Island, Japan (SHAROP). Environ. Sci., Hokkaido, 10, 109-128.

Kobayashi, F., K. Kikuchi and H. Uyeda, 1992: Merging processes of band echoes observed by radar in the winter monsoon seasons in Hokkaido. J. Fac. Sci., Hokkaido Univ., Ser. VII (Geophys.), 9, 303-316.

Kuettner, J.P., 1971: Cloud bands in the earth's atmosphere: Observations and theory. Tellus, 23, 404426.

Lavoie, R.L., 1972: A mesoscale numerical model of lakeeffect storms. J. Atmos. Sci., 29, 1025-1040.

Sakakibara, H., M. Ishihara and Z. Yanagisawa, 1988: Squall line like convective snowbands over the Sea of Japan. J. Meteor. Soc. Japan, 66, 937-953. 


\title{
主風向に平行な走向を持つ筋状降雪雲の 2 台のドップラーレーダを用いた研究 第 2 部：筋状降雪雲の運動学が隣接する筋状降雪雲の発達に及ぼす影響
}

\author{
吉本直弘 \\ (大阪教育大学) \\ 藤吉康志 \\ (北海道大学低温科学研究所) \\ 武田喬男 \\ (名古屋大学大気水圈科学研究所)
}

2 本の主風向に平行な走向を持つ筋状降雪雲 (バンド I と II) が、冬期寒気吹き出し時に北海道石狩湾上 で観測された。筋状降雪雲 (バンド II) の運動学的構造を 2 台のドップラーレーダの観測データを用いて 3 次元的に詳しく調べた。バンド II は石狩湾上で急激に発達した。帯状の高反射強度 (最大約 $35 \mathrm{dBZ}$ ) 域が バンドの走向に沿って形成され、バンド II のレーダエコー構造を特徽づけていた。バンド II の帯状の高 反射強度域は、バンドの走向に直交する鉛直断面内の循環が卓越した気流構造を持っていた。

2 本の筋状降雪雲間の相互作用を議論した。興味深い事実として、下層で 2 本の筋状降雪雲を繋ぐレー ダエコーの橋が観測された。レーダエコーの橋はバンド I を構成するメソ らの下層の外出気流に関連して形成された。下層の外出気流は時間とともにバンド II に向かって移動し、 バンド II 内部に進入した。これはバンド II 内部で下層の強い収束と上昇気流の強化を引き起こした。そ の結果、より強いレーダエコーがバンド II 内部で形成され、バンド II は急速に発達した。下層の外出気 流によってバンド I からバンド II へ降雪粒子が輸送された。これらの降雪粒子はバンド II 内部の強化し た上䄯気流中で急速に成長し、バンド II の急速な発達に寄与したと考えられた。 